\title{
Evaluation of antimicrobial and antioxidant attributes of Tanzanian honey from two agro-ecological areas
}

\author{
FLORA THOMAS LUVANDA, MONICA E. LYIMO \\ Department of Food Technology, Nutrition and Consumer Sciences, College of Agriculture, Sokoine University of Agriculture. Morogoro, Tanzania \\ vemail: monilyimo@yahoo.com
}

Manuscript received: 3 March 2018. Revision accepted: 25 August 2018.

\begin{abstract}
Luvanda FT, Lyimo ME. 2018. Evaluation of antimicrobial and antioxidant attributes of Tanzanian honey from two agroecological areas. Biofarmasi J Nat Prod Biochem 16: 69-82. In order to appraise the characteristic of Tanzanian honey based on antioxidant attributes and antimicrobial activity on bacteria and fungi about its physicochemical attributes, the study was conducted. The examined honey was sampled from two kinds of bees: stinging and stingless honey bees. It was gathered from the western area (Tabora and Shinyanga) and the central area (Singida and Dodoma). They were examined for their antimicrobial activity, anti-oxidant attributes (total phenol, vitamin $\mathrm{C}$ ), and physicochemical attributes of $\mathrm{pH}$, color, $\mathrm{pH}$, sugar, and minerals. $54 \%$ of tested honey samples inhibited microbial growth, but the remaining 46\% did not inhibit the growth. Microbial impediment areas range from 8.5 to $14.16 \mathrm{~mm}$ (stinging honey bee) and 10.56 to $15.13 \mathrm{~mm}$ (stingless honey bee). Honey yielded by stinging honey bees Shinyanga, Bukombe, and Nzega and the cities of Singida and Issuna are more effective in impeding microbial growth than that other cities. Candida albicans is more sensitive (23.1\%) to honey than stingless honey bees, followed by Staphylococcus saprophyticus (33\%), Salmonella typhi (32\%), Escherichia coli (19.2\%), and Aspergillus flavus (16.0\%). The substance of antioxidant, total phenol, and vitamin C in the honey of stingless honey bees were importantly $(\mathrm{P}<0.05)$ higher than that of honey of stinging honey bees. Antioxidants (FRAP) ranged from 322.16-973.57 $\mu \mathrm{MFe}$ (II) $/ 100 \mathrm{~g}$, total phenols were from $13.87-33.55 \mathrm{mg} / 100 \mathrm{~g}$, and vitamin $\mathrm{C}$ was from $2.54-10.99 \mathrm{mg} / 100$. There was no substantial dissimilarity $(\mathrm{P}>0.05)$ between the two honey samples at $\mathrm{pH}$ value. Potassium possesses the highest value, while $\mathrm{Zn}$ possesses the lowest value in honey samples of stinging and stingless honey bees. The gradation color of honey of stingless honey bees ranged from extra light amber-light amber, while that of honey of stinging bees ranged from white water-light amber. There was a positive and substantial correlation $(\mathrm{P}<0.001)$ between the color of honey, antioxidants, total phenol, and mineral substance. Stingless honey bees' honey from the western region is superior to stinging honey bees' honey in terms of antioxidant and antimicrobial attributes. Therefore, it is prompted to be utilized as a valuable diet product, preventive and curative medicine.
\end{abstract}

Keywords: Agro-ecological areas, antimicrobial, antioxidant, honey, Tanzanian

\section{INTRODUCTION}

Honey is an organic natural sweet substance yielded from nectar and saccharine exudation of plants by honey bees recognized as Apis mellifera and Trigona meliponini (Codex Standard 2001). The nectar of flowers is stockpiled, modified, stashed in the comb, and altered by honey bees into honey by regurgitation and evaporation (Stefan 2009).

Honey is a natural product with several characteristics that are advantageous for human beings. It is believed to be significant in human nutrition and health (Alisi et al. 2012). For thousands of years (since $2100 \mathrm{BC}$ ), archaic Greeks utilized honey as a traditional diet and healing agent (Alisi et al. 2012). Its attributes cause it to be capable of acting as a natural diet with antioxidants and antimicrobial, which are conscientious of its medicinal attributes. It possesses robust immune procedure stimulus and carbohydrates that supply power and energy to the body. The availability of enzymes in honey succors increases the digestive procedure and reduces muscle lethargy in the body (Rodriguez 2004).

Dissimilar kinds of honey possess dissimilar mixtures depending on the kind of honey bees, geographical origin, and maturity attribute of honey before reaping (Alvarez et al. 2010). Honey is composed of carbohydrates, enzymes hydroxymethylfurfural (HMF), proteins, minerals, amino acids, vitamins, and antioxidants such as phenolics and flavonoids (Candiracci et al., 2012). Its health advantage is related to the availability of these precious nutrients and phytochemicals.

The most honey-yielding and consuming nations globally are China, Turkey, Argentina, and Mexico (FAOSTAT 2014). Tanzania possesses the capability of yielding 138,000 metric tons of honey every year. Almost all areas participate in beekeeping and honey production. The primary beekeeping and honey production areas are the Western area (Tabora, Shinyanga, Rukwa, and Kigoma), Southern Area (Lindi, Mbeya, Iringa, and Ruvuma), Central Area (Singida and Dodoma), Eastern Area (Morogoro, Dar es Salaam and Coast) and North Eastern Area (Manyara, Arusha, Tanga, and Kilimanjaro). In Tanzania, honey is yielded from dissimilar provenances involving plants (perennial plants, fruits, sunflower, palm oil, rice, maize, sorghum), soil, and dissimilar geographical origins such as arid, wet, or coast (URT 2003). Tanzania possesses a tropical climate with regional diversity because of the topography (nation's landscape). The temperature is high in the primary land and tropical in the coastal areas 
and the islands. The excellent climate diversity in Tanzania results in diversity in Tanzania's flora and fauna.

Currently, the consumption of honey is rising due to its advantageous biological and physical-chemical attributes, involving antioxidant and antibacterial activities. More than half of the honey yielded in the nation is consumed locally for diet and medicine. At the same time, the rest is sold to other nations, particularly European Union member nations such as the UK, Netherlands, and Germany. Other nations are Oman, United Arab Emirates, Iran, Uganda, Kenya, and Rwanda (Mwakatobe and Mlingwa 2004).

The objectives of this research were: (i) To specify the antimicrobial activities of bacteria (Staphylococcus saprophyticus, Escherichia coli, and Salmonella typhi) and fungi (Aspergillus flavus and Candida albicans) the on the raw honey from stinging and stingless honey bees. (ii) To evaluate raw honey's physicochemical attributes $(\mathrm{pH}$, decreasing sugar and minerals) from stinging and stingless honey bees. (iii) To investigate the raw honey's antioxidant activities (total phenol and vitamin C) in stinging and stingless honey bees. (iv) To correlate the physicochemical attributes of honey to the antioxidant and antimicrobial attributes of raw Tanzanian honey from stinging and stingless honey bees.

\section{MATERIAL AND METHODS}

\section{Materials}

Two kinds of honey, i.e., raw honey of stinging and stingless honey bees, were gathered from beekeepers in two selected agro-ecological areas of Tanzania; the Western area, including Tabora (Inyonga, Tabora town, and Nzega) and Shinyanga (Kahama, Bukombe, and Shinyanga town), Central area including Singida (Issuna, Manyoni and Singida town) and Dodoma (Kibaigwa, Bahi, and Dodoma town). The central area of Tanzania is mostly savanna, bushland, and thickets, whereas the western area is embodied mostly by miombo woodland trees.

The bacteria (S. saprophyticus, E. coli, S. typhi) and fungi (A. flavus and $C$. albicans) to participate in the test organism were achieved from Veterinary Microbiology Laboratory, Sokoine University of Agriculture (SUA), Morogoro.

\section{Methods}

Sampling procedure

A purposive sampling method was utilized to pick out areas, followed by a simple random sampling method to gather honey samples from beekeepers in two selected areas (Western and Central) of Tanzania. Two kinds of honey were gathered in triplicate from each sampling area (3 replications). Thus, 3 replicates per honey kind $\mathrm{x} 2$ honey bee kinds $\mathrm{x} 3$ sampling areas $\mathrm{x} 2$ regions in each area $=36$ honey samples from each area, making a total of 72 honey samples gathered from the two areas. The honey samples were packaged in sterilized plastic bottles (330 $\mathrm{mL})$, transported at ambient temperature $\left(25 \pm 2^{\circ} \mathrm{C}\right)$, and stashed at the Laboratory of Food Technology, Nutrition, and Consumer Sciences, SUA, Morogoro.

\section{Research design}

The study utilized a completely randomized block design in a factorial experiment with 3 replications. The principal factors were located at two levels (two areas) and bee kind at two levels (honey of sting honeybees and stingless honey bees). The effect of these factors on $\mathrm{pH}$, decreasing sugar, color, antioxidant activity, antimicrobial activity, vitamin $\mathrm{C}$, minerals, and total phenol was considered. The following model was assumed.

$Y_{i j k l}=\mu+Z_{i}+R_{j}+A_{k}+T_{l}+\left(Z^{*} R^{*} A * T\right)_{i j k l}+e_{i j k l}, \ldots \ldots(1)$

Where $\mathrm{Y}_{\mathrm{ijkl}}=$ Dependent variable, $\mu=$ General mean, $\mathrm{Z}_{\mathrm{i}}=$ the effect of $i^{\text {th }}$ agro-ecological area, $R_{j}=$ Effect of $j^{\text {th }}$ sampling region $A_{k}=$ Effect of $k^{\text {th }}$ sampling area $T_{l}=$ The effect of an $\mathrm{l}^{\text {th }}$ honey kind, $(\mathrm{Z} * \mathrm{R} * \mathrm{~A} * \mathrm{~T})_{\mathrm{ijkl}}=$ Interaction effect between $\mathrm{i}^{\text {th }}$ area $\mathrm{j}^{\text {th }}$ region $\mathrm{k}^{\text {th }}$ area and $\mathrm{l}^{\text {th }}$ honey kind $\mathrm{e}_{\mathrm{ijkl}}=$ Error term or Random term.

\section{Antimicrobial sensitivity test}

SpecifiedAgar Wells Diffusion technique, as described by Clinical Laboratory Typical Institute (2009), was utilized to consider the antimicrobial sensitivity test of the honey samples. To test antimicrobial susceptibility, Mueller-Hinton Agar medium was utilized, and following the manufacturer's instructions, the medium was arranged. After autoclaving $\left(121^{\circ} \mathrm{C}\right.$ for $15 \mathrm{~min}$.), the medium was left to cool to $50^{\circ} \mathrm{C}$. Then $25 \mathrm{~mL}$ per plate $(15 \times 100 \mathrm{~mm})$ was quantified on a level pouring surface to a uniform depth of $4 \mathrm{~mm}$ and hatched in an incubator $\left(35 \pm 2^{\circ} \mathrm{C}\right)$ for 24 hours.

The test organisms comprised of bacteria (Staphylococcus saprophyticus, E. coli, S. typhi) and fungi (A. flavus and C. albicans), and they were streaked onto a non-inhibitory agar medium (broth agar) to gain isolated colonies. After hatching at $35^{\circ} \mathrm{C}$ overnight, 4 to 5 colonies were selected, injected into the broth (Mueller-Hinton broth), and hatched at $35^{\circ} \mathrm{C}$ for 24 hours. A sterile cotton swab was dipped into the suspension, pressed firmly against the inside wall of the tube just above the fluid level, then streaked over the entire surface of the medium, rotating the plate approximately 60 degrees after each administration to ensure an equal location of the inoculum, finally swabbed all around the edge of the agar surface. Small holes of $5 \mathrm{~mm}$ were created on the Petri dishes with agar using glass pastor and sterile loops, then $100 \mu \mathrm{L}$ of the honey sample was situated in the agar holes using a sterile micropipette. The plates were inverted and hatched at 37 $\pm 1^{\circ} \mathrm{C}$ for 24 hours for tested bacteria and 48 hours for yeast. After the hatching period, the diameter of the areas of complete impediment (involving the disk's diameter) was quantified and recorded in millimeters. The quantifications were performed with a ruler on the undersurface of the plate without opening the lids.

\section{Chemical analyses \\ Antioxidant activity}

By using the Ferric reducing ability of plasma (FRAP) assessment following the method described by Benzie and Strain (1996), antioxidant activity in honey samples was specified. About $0.1 \mathrm{~g}$ of honey was liquefied with refined 
water and made up to $10 \mathrm{~mL}$. Then $200 \mu \mathrm{L}$ of liquefied honey $(0.1 \mathrm{~g} / \mathrm{mL})$ was blended with $1.5 \mathrm{~mL}$ of FRAP reagent. The reaction mixture was then hatched at $37^{\circ} \mathrm{C}$ for 4 minutes, and its absorbance was quantified spectrophotometrically at $593 \mathrm{~nm}$ against a blank arranged with refined water. Fresh FRAP reagent was arranged by mixing 10 volumes of $300 \mathrm{mM} / \mathrm{l}$ acetate buffer $(\mathrm{pH} \mathrm{3.6)}$ with 1 volume of $10 \mathrm{mM} \mathrm{TPTZ} \mathrm{(2,} \mathrm{4,} \mathrm{6-tripyridyl-s-}$ triazine) solution in $40 \mathrm{mM} / 1 \mathrm{HCl}$, containing 1 volume of $20 \mathrm{mM}$ ferric chloride $\left(\mathrm{FeCl}_{3} \cdot 6 \mathrm{H}_{2} \mathrm{O}\right)$. Trolox (vitamin $\mathrm{E}$ analog) was used for the calibration curve with serial dilutions of $0,25,50,100,150,200,250$, and $300 \mu \mathrm{M} / \mathrm{mL}$.

The typical curve was plotted, and the unknowns were computed using the linear regression equation of the typical plot. The ferric reducing ability of the honey sample was described as FRAP value ( $\mu \mathrm{M}$ of $\left.\mathrm{Fe}^{\mathrm{II}}\right)$ per $100 \mathrm{~g}$ of honey as per the following formula:

$$
\begin{aligned}
& \text { FRAP value }\left(\frac{\mu \mathrm{M} \mathrm{Fe}(\mathrm{II})}{100 \mathrm{~g}}\right)= \\
& \frac{\text { Change in absorbance of sample }}{\text { Change in absorbance of standard }} \times \text { FRAP value of typical }
\end{aligned}
$$

\section{Vitamin $C$ determination}

According to the AOAC (2007) procedure using method number 967.21, vitamin C (Ascorbic acid) was specified based on the oxidation-reduction reaction principle. Using $10 \mathrm{~mL}$ of $10 \%$ Trichloroacetic acid (TCA), about $5 \mathrm{~g}$ of the homogenized honey sample was weighed and extracted, and the extract was gathered into a volumetric flask. Then, using Whatman sieve paper No.1, the liquefied sample extract was sifted. Next, $10 \mathrm{~mL}$ of the clear filtrate was pipetted into a $250 \mathrm{~mL}$ Erlenmeyer flask. A blank solution was arranged using $10 \mathrm{~mL}$ of $10 \%$ TCA solution. The burette was filled with a typical indophenol solution. Slowly, the flask contents were titrated with a typical indophenol solution until the faint pink color was achieved and existed for 10 seconds. The volume of indophenol solution utilized to oxidize the ascorbic acid present in the sample extract and the blank solution was recorded. Then vitamin $\mathrm{C}$ substance in the honey sample extract was computed using the following formula:

Vitamin $C$ substance of the sample $(\mathrm{mg} / 100 \mathrm{~g})=$ $\underline{(A-B) \times C \times V \times 100}$

$$
\mathrm{D} \times \mathrm{S}
$$

Where;

$\mathrm{A}=$ Volume in $\mathrm{mL}$ of the indophenol solution utilized for the sample

$\mathrm{B}=$ Volume in $\mathrm{mL}$ of the indophenol solution utilized for blank

$\mathrm{C}=$ Mass in $\mathrm{mg}$ of ascorbic acid equivalent to $1.0 \mathrm{~mL}$ indophenols solution

$\mathrm{S}=$ Mass of sample in $(\mathrm{g})$ taken for analysis

$\mathrm{V}=$ Total volume of extract in milliliters

$\mathrm{D}=$ Volume of sample filtrate in milliliters taken for analysis

\section{Total phenolic compound}

Using the Folin-Ciocalteu reagent (FCR) described by Singleton et al. (1999), the total phenol of the honey samples was specified. Each sample was analyzed using the spectrophotometer Wagtech CECIL 2021, and a $20 \mu \mathrm{L}$ sample was added to $100 \mu \mathrm{L}$ FCR (liquefied 1: 10 with refined water), blended hatched at $37^{\circ} \mathrm{C}$ for 60 seconds before the addition of $80 \mu \mathrm{L} 7.5 \%(\mathrm{w} / \mathrm{v})$ sodium bicarbonate solution. The samples were blended again and hatched at $37^{\circ} \mathrm{C}$ for 15 minutes prior to absorbance reading at $760 \mathrm{~nm}$. Total phenol was computed against a calibrated typical curve of gallic acid, and the results were expressed as mg gallic acid equivalents (GAE) per 100 sample weight (SW).

$$
\begin{aligned}
& \text { Total phenol }\left(\frac{\mathrm{mg}}{100 \mathrm{~g}}\right)= \\
& \frac{\text { Reading value in ppm x Dilution factor } \times 100}{\text { sample weight }}
\end{aligned}
$$

\section{pH determination}

Using a digital portable $\mathrm{pH}$ meter-JENWAY, UK $3305 \mathrm{P}$, in accordance with Harmonised International Honey Commission (2009), the $\mathrm{pH}$ of honey samples was specified. In between the readings of dissimilar samples, the electrode was washed with refined water, dried with tissue paper, slipped into prepared honey samples, and recorded. The experiment was performed in triplicates.

\section{Color determination}

According to the USDA Honey Colour Grading Chart (USDA 1985), the classification of honey color was named and assigned a rank. Honey samples were situated in clean and clear McCartney bottles and determined against the color grading chart by Panoramic Hill Honey Collective (2013).

\section{Determination of total decreasing sugar}

Following the AOAC (2000) procedure using method number 920.183, the total decreasing sugar of honey was specified. About $1 \mathrm{~g}$ of honey sample in conical flask was deliquesced using $100 \mathrm{~mL}$ hot water to deliquesce all sugars. The solution was purified by adding $5 \mathrm{~mL}$ Carrez 1 solution followed by Carrez 2 solution; then, the substance was sifted with Whatman sieve paper No. 1. Then, $10 \mathrm{~mL}$ of the filtrate was situated in duplicate in a conical flask blended with $10 \mathrm{~mL}$ of copper reagent (sodium carbonate solution, copper sulphate solution, and citric acid), then boiled for 30 minutes and left to cool; after that, $1 \mathrm{~mL}$ of saturated solution KI was added followed by $10 \mathrm{~mL}$ of $6 \mathrm{~N}$ HCL. About three drops of $1 \%$ w/v starch were added as an indicator, and the substance was titrated against $0.1 \mathrm{~N}$ $\left(\mathrm{NaS}_{2} \mathrm{O}_{3}\right)$ up to the endpoint (blue-black to cream). Luff Table was utilized after titration volume to sugar substance, and the amount of decreasing sugar per gram of honey samples was computed as follows:

Amount of total decreasing sugar in the original sample $(\mathrm{mg} / \mathrm{g})=$

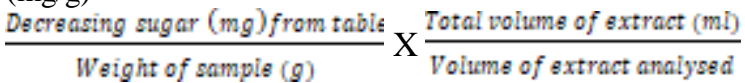




\section{Mineral analysis}

According to AOAC (2000) procedures using method number 999.11 by Atomic Absorption Spectrophotometer (AAS UNICAM 919) and Flame Analyzer (Model 2655$00)$, the mineral substance of honey samples (Fe, K, Zinc, $\mathrm{Ca}, \mathrm{Mg}$ ) were specified About $5 \mathrm{~g}$ of honey samples were burnt in the muffle furnace at $550^{\circ} \mathrm{C}$ for 4 hours and ash substance of each sample was deliquesced using $10 \mathrm{~mL}$ of $6 \mathrm{~N} \mathrm{HCl}$. The achieved ash solution was sifted using Whatman sieve paper No.1. The serially liquefied reference typical solutions for Atomic Absorption Spectrophotometer (Element wavelength flame-gases) were; zinc $213.9 \mathrm{~nm}$, iron $248.3 \mathrm{~nm}$, potassium $766.5 \mathrm{~nm}$, calcium $422.7 \mathrm{~nm}$, and Magnesium $285.2 \mathrm{~nm}$.

The Typical curve plot of absorbance against the recognized concentration of typical solutions $(0.5,1,1.5$, 2.0, 2.5, and $3.0 \mathrm{ppm}$ ) was utilized to specify the concentration of minerals in samples and expressed as in the following formula.

Mineral content $=$

$\left(\frac{\mathrm{mg}}{100 \mathrm{~g}}\right) \frac{\text { Reading Value in ppm } \mathrm{x} \text { Dilution factor } \mathrm{x} 100}{\text { Sample weight }(\mathrm{g})}$

\section{Statistical data analysis}

Data achieved from antimicrobial analysis, antioxidant analysis, and physicochemical analysis were examined using SAS software (version 9.1) for Analysis. Analysis of Variance (ANOVA) was utilized to specify the effect of the primary factor on the dependent variables; the factor effect was believed to be substantial when $\mathrm{p}<0.05$. Mean comparison was performed using the probability of difference (pdiff), and results were expressed as Least Squares Mean \pm SE. Statistical Package for Social Scientists (SPSS, Version 17) software was utilized to appraise the percentage of various quantified parameters.

\section{RESULTS AND DISCUSSION}

\section{Antimicrobial properties of raw honey from stinging and stingless bee honey}

Tables 1.A, B, and C declare the capability of honey to inhibit microbial growth from selected areas, regions, and areas, respectively. Table 1.D shows two kinds of honey gathered from various honey-yielding areas, neighborhoods, and areas concerning its capability to inhibit micro-organism growth. Honey gathered from the western area had more capability of impeding microbial growth than that from the central area. However, the impediment area (diameter) between the western and central area was not important $(\mathrm{P}>0.05)$ dissimilar (Table 1.A).

Honey from Tabora and Shinyanga in the western area and Singida in the central area had a relatively higher capability to inhibit microbial growth than honey from Dodoma. Shinyanga honey showed a significantly larger area diameter of impediment, followed by Singida, Dodoma, and Tabora (Table 1.B).
The areas where honey samples were gathered are clearly displayed in Table 1.C shows honey samples from Nzega and Inyonga had the highest capability to resist microbial growth, followed by samples from Shinyanga town Bukombe and Kahama. In contrast, honey from Kibaigwa in the Dodoma region presented the lowest capability to resist microbial growth and, importantly, $(\mathrm{P}<0.05)$ lowest impediment area. The dissimilarity incapability to inhibit microbial growth could probably be because of dissimilar vegetation kinds between these areas (Kumar et al. 2010). Dissimilar vegetation contains dissimilar floral kinds that vary in pollen and nectar, influencing the honey mixture.

Table 1.A. Effect of honey gathered from central and western areas of Tanzania on microbial growth $(\mathrm{N}=360)$

\begin{tabular}{lccc}
\hline Area & \multicolumn{2}{c}{ Response\% } & Inhibition area \\
\hline & $+\mathrm{Ve}$ & $-\mathrm{Ve}$ & $(\mathrm{mm})$ \\
Central & 22.2 & 27.8 & $11.87 \pm 0.43^{\mathrm{a}}$ \\
Western & 31.9 & 18.1 & $12.24 \pm 0.30^{\mathrm{a}}$ \\
Total/Significance level & 54.2 & 45.8 & $\mathrm{NS}$ \\
\hline
\end{tabular}

Note: $\mathrm{NS}=$ Not substantial at $\mathrm{P}>0.05 ;+$ ve response $=$ Ability of honey to inhibit microbial growth; -ve response = Inability of honey to inhibit microbial growth

Table 1.B. Effect of honey gathered from various areas of Tanzania on the response of microbial growth $(\mathrm{N}=360)$

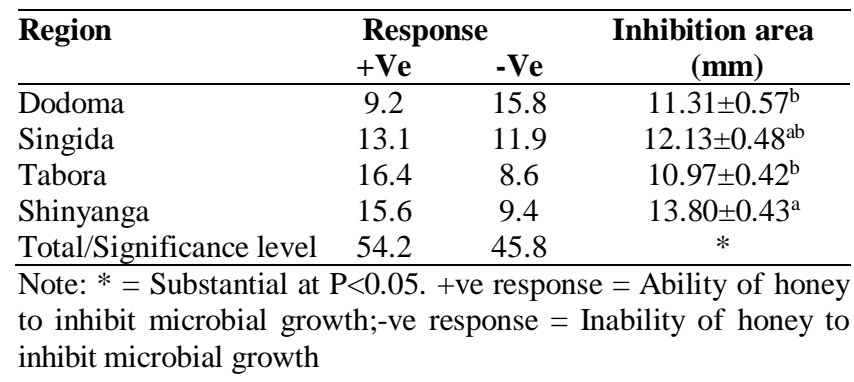

Table 1.C. Effect of honey gathered from various areas of Tanzania on microbial growth $(\mathrm{N}=360)$

\begin{tabular}{lccc}
\hline Areas & \multicolumn{2}{c}{ Response } & Inhibition area \\
\hline Kibaigwa & $+\mathbf{V e}$ & $\mathbf{- V e}$ & $(\mathbf{m m})$ \\
Dodoma town & 2.5 & 5.8 & $9.78 \pm 1.04^{\mathrm{c}}$ \\
Bahi & 3.1 & 5.3 & $13.80 \pm 0.99^{\mathrm{a}}$ \\
Issuna & 3.6 & 4.7 & $10.46 \pm 0.87^{\mathrm{bc}}$ \\
Manyoni & 4.4 & 3.9 & $13.63 \pm 0.78^{\mathrm{a}}$ \\
Singida town & 4.2 & 4.2 & $10.60 \pm 0.81^{\mathrm{bc}}$ \\
Nzega & 4.4 & 3.9 & $12.06 \pm 0.81^{\mathrm{b}}$ \\
Inyonga & 5.8 & 2.5 & $10.90 \pm 0.68^{\mathrm{bc}}$ \\
Tabora town & 5.8 & 2.5 & $10.62 \pm 0.68^{\mathrm{bc}}$ \\
Kahama & 4.7 & 3.6 & $11.47 \pm 0.76^{\mathrm{b}}$ \\
Bukombe & 5.0 & 3.3 & $13.78 \pm 0.74^{\mathrm{a}}$ \\
Shinyanga town & 5.0 & 3.3 & $15.11 \pm 0.74^{\mathrm{a}}$ \\
Total/Significance level & 5.6 & 2.8 & $12.65 \pm 0.70^{\mathrm{b}}$ \\
\hline
\end{tabular}

Note: $*=$ Substantial at $\mathrm{P}<0.05 ;+\mathrm{ve}$ response $=$ Capability of honey to inhibit microbial growth;-ve response = Incapability of honey to inhibit microbial growth 
Table 1.D. The ability of stingless and stinging honey bees from central and western areas in Tanzania to inhibit microbial growth $(\mathrm{N}=$ 360)

\begin{tabular}{|c|c|c|c|c|c|c|}
\hline \multirow[t]{2}{*}{ Area } & \multirow[t]{2}{*}{ Region } & \multirow[t]{2}{*}{ Area } & \multirow[t]{2}{*}{ Honey type } & \multicolumn{2}{|c|}{ Response\% } & \multirow[t]{2}{*}{ Inhibition area $(\mathrm{mm})$} \\
\hline & & & & $+\mathrm{Ve}$ & $-\mathrm{Ve}$ & \\
\hline \multirow{15}{*}{ Central } & \multirow[t]{2}{*}{ Dodoma } & \multirow[t]{2}{*}{ Bahi } & Stingless & 3.24 & 0.8 & $10.79 \pm 0.88^{\mathrm{b}}$ \\
\hline & & & Stinging & 0.2 & 3.78 & $12.16 \pm 3.06^{\mathrm{b}}$ \\
\hline & \multirow{10}{*}{ Singida } & \multirow[t]{2}{*}{ Town } & Stingless & 2.43 & 1.62 & $13.25 \pm 2.16^{\mathrm{a}}$ \\
\hline & & & Stinging & 0.54 & 3.5 & $10.16 \pm 1.08^{\mathrm{bc}}$ \\
\hline & & \multirow[t]{2}{*}{ Kibaigwa } & Stingless & 2.43 & 1.62 & $10.56 \pm 1.02^{\mathrm{b}}$ \\
\hline & & & Stinging & 0 & 4.1 & NA \\
\hline & & \multirow[t]{2}{*}{ Issuna } & Stingless & 4.1 & 0 & $13.40 \pm 0.79^{\mathrm{a}}$ \\
\hline & & & Stinging & 0.27 & 3.78 & $14.16 \pm 1.53^{\mathrm{a}}$ \\
\hline & & \multirow[t]{2}{*}{ Manyoni } & Stingless & 3.24 & 0.8 & $11.71 \pm 0.88^{\mathrm{b}}$ \\
\hline & & & Stinging & 3.5 & 3.24 & $9.51 \pm 1.76^{\mathrm{c}}$ \\
\hline & & \multirow[t]{2}{*}{ Town } & Stingless & 4.1 & 0 & $11.82 \pm 0.82^{\mathrm{b}}$ \\
\hline & & & Stinging & 0.27 & 3.78 & $12.16 \pm 3.06^{\mathrm{b}}$ \\
\hline & \multirow[t]{3}{*}{ Tabora } & \multirow[t]{2}{*}{ Inyonga } & Stingless & 3.78 & 0.27 & $11.27 \pm 0.92^{\mathrm{b}}$ \\
\hline & & & Stinging & 1.89 & 2.16 & $10.21 \pm 1.25^{\mathrm{bc}}$ \\
\hline & & \multirow[t]{2}{*}{ Nzega } & Stingless & 4.1 & 0 & $11.33 \pm 0.79^{b}$ \\
\hline \multirow{9}{*}{ Western } & \multirow{9}{*}{ Shinyanga } & & Stinging & 1.62 & 2.43 & $8.67 \pm 1.25^{\mathrm{d}}$ \\
\hline & & \multirow[t]{2}{*}{ Town } & Stingless & 2.97 & 1.08 & $12.13 \pm 0.92^{\mathrm{b}}$ \\
\hline & & & Stinging & 1.62 & 2.43 & $8.88 \pm 1.25^{\mathrm{d}}$ \\
\hline & & \multirow[t]{2}{*}{ Bukombe } & Stingless & 4.1 & 0 & $15.13 \pm 0.79^{\mathrm{a}}$ \\
\hline & & & Stinging & 0.8 & 3.24 & $12.16 \pm 1.37^{\mathrm{b}}$ \\
\hline & & \multirow[t]{2}{*}{ Kahama } & Stingless & 3.78 & 0.27 & $14.63 \pm 0.82^{\mathrm{a}}$ \\
\hline & & & Stinging & 1.08 & 2.97 & $10.34 \pm 1.53^{\mathrm{bc}}$ \\
\hline & & \multirow[t]{2}{*}{ Town } & Stingless & 4.1 & 0 & $13.53 \pm 0.79^{\mathrm{a}}$ \\
\hline & & & Stinging & 1.35 & 2.70 & $8.50 \pm 1.37^{\mathrm{d}}$ \\
\hline
\end{tabular}

Note: Means bearing the same superscript along the column are not statistically dissimilar according to pdiff at $\mathrm{P}>0.05 ;+\mathrm{ve}$ response $=$ Ability of honey to inhibit microbial growth;-ve response = Inability of honey to inhibit microbial growth

Table 2. The effect of honey kinds on the growth of pathogenic micro-organisms $(\mathrm{N}=360)$

\begin{tabular}{|c|c|c|c|c|}
\hline \multirow[t]{2}{*}{ Honey kind } & \multirow[t]{2}{*}{ Micro-organism } & \multicolumn{2}{|c|}{ Response \% } & \multirow{2}{*}{$\begin{array}{c}\text { Inhibition area } \\
\text { mm }\end{array}$} \\
\hline & & $+\mathrm{Ve}$ & $-\mathrm{Ve}$ & \\
\hline \multirow[t]{5}{*}{ Stingless } & Escherichia coli & 19.2 & 25.0 & $9.22 \pm 0.54^{\mathrm{b}}$ \\
\hline & Salmonella typhi & 20.5 & 16.7 & $10.47 \pm 0.53^{\mathrm{ab}}$ \\
\hline & Staphylococcus saprophyticus & 21.2 & 12.5 & $10.86 \pm 1.22^{\mathrm{ab}}$ \\
\hline & Candida albicans & 23.1 & 0.0 & $11.67 \pm 0.50^{\mathrm{a}}$ \\
\hline & Aspergillus flavus & 16.0 & 45.8 & $10.97 \pm 0.60^{\mathrm{ab}}$ \\
\hline Sub-Total & & 100.0 & 100.0 & \\
\hline \multirow[t]{5}{*}{ Stinging } & Escherichia coli & 0.0 & 25.5 & 0.0 \\
\hline & Salmonella typhi & 7.7 & 23.4 & $0.83 \pm 0.06^{\mathrm{f}}$ \\
\hline & Staphylococcus saprophyticus & 15.4 & 21.3 & $1.78 \pm 0.09^{\mathrm{e}}$ \\
\hline & Candida albicans & 30.8 & 17.0 & $2.89 \pm 0.10^{\mathrm{d}}$ \\
\hline & Aspergillus flavus & 46.2 & 12.8 & $6.56 \pm 0.48^{c}$ \\
\hline Sub-Total & & 100.0 & 100.0 & $* * *$ \\
\hline
\end{tabular}

Note: Means bearing the same superscript along the column are not statistically different according to pdiff at $\mathrm{P}>0.05 ;+\mathrm{ve}$ response $=$ Ability of honey to inhibit microbial growth;-ve response = Inability of honey to inhibit microbial growth

This study presented that about $54 \%$ of all tested honey samples, regardless of the kind of honey or the area gathered, or the tested microorganism, presented a positive response to impede microbial growth, whereas $46 \%$ presented a negative response (Table 1.C). Incapability to inhibit microbial growth could be attributed to the vegetation where these honey samples were gathered, with contents of nectar and pollen that do not possess medicinal attributes that can kill pathogenic microorganisms (Manning 2000). Alternatively, the tested honey could not influence the pathogenic microorganisms utilized to test honey impediment.

Results in Table 1.D further comply that stingless honey had more capability to impede microbial growth than a stinging honey bee, suggesting that a stingless honey bee possesses higher medicinal attributes than the stinging honey bee. The superiority of the stingless honey bees could be attributed to the flowers and trees visited. Also, stingless bees do not blend pollen with honey, whereas larger bees blend honey and pollen together to produce the so-called bee bread (Cortopassi et al. 2006). Another 
reason could be the smaller size $(5 \mathrm{~mm})$ of the stingless bee, which enables the bees to penetrate more into the flower and extract medicinal ingredients than larger bees that can't penetrate deep into the flower (Roubik 2006).

The microbial impediment area ranged from 8.5 (stinging honey bee) to $15.13 \mathrm{~mm}$ (stingless honey). The observed impediment area in this study is more or less similar to that informed by Rahman et al. (2010) (13-15). They worked with honey and propolis samples that presented the capability to inhibit the growth of E. coli and Staphylococcus aureus, where propolis attained a higher impediment limit. Mohapatra et al. (2010) informed higher impediment area resulted from raw and processed honey from India on gram-positive bacteria ( $S$. aureus, B. subtilis, B. cereus, E. faecalis, and Micrococcus luteus) and gramnegative bacteria (E. coli, $P$. aeruginosa and S. typhi) where impediment area ranged from $6.94 \mathrm{~mm}$ to $37.97 \mathrm{~mm}$. The informed upper limit is higher than the observed upper limit in this study. The dissimilarity could be attributed to dissimilarities in vegetation kind, honey processing, and kind of tested micro-organisms.

The effectiveness of stingless and stinging honey bees in inhibiting the growth of microorganisms is shown in Table 2. The results presented that $C$. albicans was more influenced by stingless honey bees, followed by $S$. saprophyticus, S. typhi, E. coli, and A. flavus.

The growth of $E$. coli was not influenced by stinging honey at all; on the contrary, A. flavus and $C$. albicans were more influenced. Bacteria are more resistant than fungi because bacteria cells possess a high spontaneous mutation rate (about 10-7 per cell division. This means that they can change their characteristics rapidly, thus, providing a greater diversity on which natural selection can act, which helps them survive in an ever-changing environment (French et al. 2005). These results are dissimilar from that informed by Mohamad (2012), who tested antimicrobial attributes of stinging honey from Mauritius using bacteria (E. coli and S. aureus) and fungal (Aspergillus niger and C. albicans) and observed that fungi were more resistant than the bacteria, this could probably be because of the concentration of honey utilized where Mohammad et al. (2012) liquefied the honey utilized while in this study honey was not diluted.

The general characteristics of honey to inhibit bacterial or fungal growth possess been explained by various scientists (Garcia et al. 1986; Wahdan 1998; Molan 1999a and Khan et al. 2007) who informed impediment of pathogenic microbial growth from the presence of hydrogen peroxide resulting from the action of glucose oxidase enzyme yielded from hypopharyngeal glands of workers bees on glucose in the presence of oxygen that inhibits microbial and fungal growth. Presence of inherent physical-chemical attributes such as high sugar substance (about $80 \% \mathrm{w} / \mathrm{w}$ ) that results in a high osmotic effect that dehydrates the micro-organisms has been informed to contribute to the impediment of microbial growth (Molan 1992; Bogdanov et al., 1997). White (1978); Aparna and Rajalashmj (1999) suggested inhibition of microbial growth is because of the presence of diverse organic acids, such as gluconic acids, that actually creates an acidic micro-environment $(\mathrm{pH} \mathrm{3-4.5)}$ that inhibits the growth of several micro-organisms. Apart from hydrogen peroxide as a factor that inhibits microbial growth, Cabrera et al. (2006) elucidated the impediment of microbial growth because of the presence of non-peroxidic substances such as polyphenols that possess anti-microbial activity.

\section{Physico-chemical properties of honey of the stingless and stinging honey bee}

\section{pH and total decreasing sugars of honey}

Results in Table 3.A declare that there was no substantial $(\mathrm{P}>0.05)$ dissimilarity in the $\mathrm{pH}$ of the honey. More importantly, total decreasing sugar was importantly $(\mathrm{P}<0.001)$ higher in honey from the western area than in the central area.

Looking at the effect of areas (Table 3.B), it is clear that honey gathered from Shinyanga had importantly $(\mathrm{P}<0.05)$ higher total decreasing sugars than that of Tabora, Singida, and Dodoma areas. The dissimilarity could be because of dissimilarity in vegetation growing in areas where the samples were gathered.

Results in Table 3.C state no substantial $(\mathrm{P}>0.05)$ variations in $\mathrm{pH}$ in honey between areas where honey samples were gathered. Honey from Shinyanga town had the highest total decreasing sugars substance (322.03 $\mathrm{mg} / \mathrm{g}$ ), and honey of Kibaigwa had the lowest total decreasing sugars substance $(172.04 \mathrm{mg} / \mathrm{g}$ ) (Table 3.C). These scrutinies suggest that honey from Shinyanga town could be a better provenance of energy to the body compared to the one gathered from Kibaigwa (Eva 1999).

Table 3.A. Effect of honey gathered from western and central zones on $\mathrm{pH}$ and total decreasing sugars substance.

\begin{tabular}{lcc}
\hline \multicolumn{1}{r}{ Area } & pH & Total decreasing sugars $(\mathbf{m g} / \mathbf{g})$ \\
\hline Central & $3.46^{\mathrm{a}}$ & $211.97^{\mathrm{b}}$ \\
Western & $3.45^{\mathrm{a}}$ & $267.58^{\mathrm{a}}$ \\
Mean & $\mathbf{3 . 4 5}$ & $\mathbf{2 3 9 . 7 7}$ \\
SE & \pm 0.02 & \pm 10.04 \\
Significance & NS & $* * *$
\end{tabular}

Note: Means bearing the same superscript within the same column are not statistically dissimilar ( $\mathrm{p} \geq 0.05$ ) according to pdiff. NS $=$ Not substantial $(\mathrm{P}>0.05)$

Table 3.B. Effect of region on $\mathrm{pH}$ and total decreasing sugars substance of honey

\begin{tabular}{lcc}
\hline \multicolumn{1}{c}{ Region } & $\mathbf{p H}$ & Total decreasing sugars $(\mathbf{m g} / \mathbf{g})$ \\
\hline Dodoma & $3.43^{\mathrm{ab}}$ & $182.62^{\mathrm{c}}$ \\
Shinyanga & $3.41^{\mathrm{b}}$ & $304.88^{\mathrm{a}}$ \\
Singida & $3.49^{\mathrm{a}}$ & $241.31^{\mathrm{b}}$ \\
Tabora & $3.48^{\mathrm{a}}$ & $230.27^{\mathrm{b}}$ \\
Significance & $*$ & $*$ \\
Overall mean & $\mathbf{3 . 4 5}$ & $\mathbf{2 3 9 . 7 7}$ \\
SE & \pm 0.02 & \pm 13.13 \\
\hline
\end{tabular}

Note: Means bearing the same superscript within the same column are not statistically dissimilar $(\mathrm{p} \geq 0.05)$ according to pdiff. * $=$ Substantial at $\mathrm{P}<0.05$ 
The present research presented that area where honey samples were gathered, honey kind, and interactions between the two factors importantly $(\mathrm{P}<0.01)$ influenced the $\mathrm{pH}$ and total decreasing sugars substance of the tested honey samples. Comparisons between sampling areas and honey kinds presented that there was no substantial $(\mathrm{P}>0.05)$ dissimilarity in $\mathrm{pH}$ between stinging and stingless honey bees (Table 3.D).

Various authors within the range inform the examined $\mathrm{pH}$ values in this study within and outside Tanzania. Muruke (2014), working with 26 honey samples from Tanzania, informed a $\mathrm{pH}$ range of 2.6 to 4.4 . The present research results also meet with those informed by Aloisi (2010), who did the research on Apis honey and informed $\mathrm{pH}$ range of 3.2-3.5. The honey samples utilized in this research seemed to be of lower $\mathrm{pH}$ than those used by Gidamis et al. (2004) while researching Tanzanian honey from Dodoma, Tanga, Morogoro, Same, Arusha, and Tabora and informed a $\mathrm{pH}$ of range of 4.4-4.87. The dissimilarity could be because of dissimilarity in soil kind and vegetation growing in areas where the samples were gathered. The honey samples in the present research might have potential medicinal attributes as their acidic nature could have yielded from organic acids, which actually produce an acidic microenvironment that inhibits pathogenic microbial growth (Aparna and Rajalakshmj 1999).

In particular, simple sugar substances, such as glucose, have been informed to have two significant roles in antimicrobial growth; one is that high sugar substances can yield a high osmotic effect that can dehydrate microbial cells (Molan 1992; Bogdanov et al. 1997). Second, gluconic acids, which actually produce an acidic microenvironment, inhibit several micro-organisms' growth (Cooper 2007). Therefore, the results of this research pose that honey of stingless honey bees from Shinyanga town, Kahama, Bukombe, and Nzega in the western area and that from Singida town and Issuna may have more medicinal attributes than that of the stinging honey bees.

Table 3.C. Effect of honey gathered from various areas on $\mathrm{pH}$ and total decreasing sugars substance.

\begin{tabular}{|c|c|c|}
\hline Area & pH & $\begin{array}{c}\text { Total decreasing sugars } \\
(\mathrm{mg} / \mathrm{g})\end{array}$ \\
\hline Bahi & $3.39^{\mathrm{a}}$ & $176.33^{\mathrm{b}}$ \\
\hline Bukombe & $3.36^{\mathrm{a}}$ & $296.52^{a}$ \\
\hline Dodoma town & $3.44^{\mathrm{a}}$ & $199.49^{b}$ \\
\hline Inyonga & $3.54^{\mathrm{a}}$ & $223.07^{\mathrm{b}}$ \\
\hline Issuna & $3.51^{\mathrm{a}}$ & $283.13^{\mathrm{a}}$ \\
\hline Kahama & $3.45^{\mathrm{a}}$ & $296.09^{a}$ \\
\hline Kibaigwa & $3.44^{\mathrm{a}}$ & $172.04^{\mathrm{b}}$ \\
\hline Manyoni & $3.48^{\mathrm{a}}$ & $245.01^{\mathrm{b}}$ \\
\hline Nzega & $3.44^{\mathrm{a}}$ & $212.52^{\mathrm{b}}$ \\
\hline Shinyanga town & $3.44^{\mathrm{a}}$ & $322.03^{\mathrm{a}}$ \\
\hline Singida town & $3.47^{\mathrm{a}}$ & $195.78^{b}$ \\
\hline Tabora town & $3.46^{\mathrm{a}}$ & $255.23^{\mathrm{b}}$ \\
\hline Overall mean & 3.45 & 239.77 \\
\hline $\mathrm{SE}$ & \pm 0.04 & \pm 22.49 \\
\hline Significance & NS & $*$ \\
\hline
\end{tabular}

Note: Means bearing the same superscript within the same column are not statistically dissimilar according to pdiff ( $\mathrm{P}>0.05)$. $\mathrm{NS}=$ Not substantial $(\mathrm{P}>0.05) *=$ Substantial at $\mathrm{P}<0.05$

Table 3.D. The effect of zones, regions, areas, and honey kinds on $\mathrm{pH}$ and total decreasing sugars substance

\begin{tabular}{|c|c|c|c|c|c|}
\hline Area & Region & Area & Honey type & pH & Total reducing sugars (mg/g) \\
\hline \multirow[t]{11}{*}{ Central } & Dodoma & Bahi & Stingless & $3.45^{\mathrm{a}}$ & $259.54^{\mathrm{cd}}$ \\
\hline & & & Stinging & $3.34^{\mathrm{a}}$ & $93.13^{\mathrm{e}}$ \\
\hline & & Town & Stingless & $3.59^{\mathrm{a}}$ & $294.78^{b c}$ \\
\hline & & & Stinging & $3.29^{\mathrm{a}}$ & $104.22^{\mathrm{e}}$ \\
\hline & & Kibaigwa & Stingless & $3.50^{\mathrm{a}}$ & $240.26^{\mathrm{d}}$ \\
\hline & & & Stinging & $3.39^{\mathrm{a}}$ & $103.82^{\mathrm{e}}$ \\
\hline & Singida & Issuna & Stingless & $3.42^{\mathrm{a}}$ & $288.94^{\mathrm{bc}}$ \\
\hline & & Manyoni & Stingless & $3.42^{\mathrm{a}}$ & $226.95^{\mathrm{cd}}$ \\
\hline & & & Stinging & $3.55^{\mathrm{a}}$ & $263.07 b^{c d}$ \\
\hline & & Town & Stingless & $3.41^{\mathrm{a}}$ & $252.92^{\mathrm{cd}}$ \\
\hline & & & Stinging & $3.53^{\mathrm{a}}$ & $138.66^{\mathrm{de}}$ \\
\hline \multirow[t]{13}{*}{ Western } & Tabora & Inyonga & Stingless & $3.41^{\mathrm{a}}$ & $204.89^{d}$ \\
\hline & & & Stinging & $3.68^{\mathrm{a}}$ & $241.25^{\mathrm{d}}$ \\
\hline & & Nzega & Stingless & $3.42^{\mathrm{a}}$ & $310.73^{b c}$ \\
\hline & & Town & Stingless & $3.41^{\mathrm{a}}$ & $303.94^{\mathrm{bc}}$ \\
\hline & & & Stinging & $3.51^{\mathrm{a}}$ & $206.53^{d}$ \\
\hline & Shinyanga & Bukombe & Stingless & $3.30^{\mathrm{a}}$ & $318.77^{b c}$ \\
\hline & & & Stinging & $3.42^{\mathrm{a}}$ & $274.27^{\mathrm{bc}}$ \\
\hline & & Kahama & Stingless & $3.42^{\mathrm{a}}$ & $413.18^{\mathrm{a}}$ \\
\hline & & & Stinging & $3.47^{\mathrm{a}}$ & $179.01^{\mathrm{d}}$ \\
\hline & & Town & Stingless & $3.41^{\mathrm{a}}$ & $320.53^{b}$ \\
\hline & & & Stinging & $3.46^{\mathrm{a}}$ & $323.53^{b}$ \\
\hline & & & $\mathrm{SE}$ & \pm 0.01 & \pm 0.12 \\
\hline & & & Significance & NS & $* * *$ \\
\hline
\end{tabular}

Note: Means bearing the same superscript within the same column are not statistically dissimilar ( $\mathrm{p} \geq 0.05)$ according to pdiff. NS=Not substantial $(\mathrm{P}>0.05) ; * * *=$ Substantial at $\mathrm{P}<0.001$ 
Table 4.A. Effect of zones on color grading of honey $(\mathrm{N}=72)$

\begin{tabular}{llc}
\hline Area & Colour & Percent \\
\hline Central & Water white & 1.4 \\
& Extra white & 5.6 \\
& White & 2.8 \\
& Extra light amber & 19.4 \\
& Light amber & 13.9 \\
& Amber & 6.9 \\
Western & Extra white & 8.3 \\
& White & 12.5 \\
& Extra light amber & 1.4 \\
& Light amber & 13.9 \\
& Amber & 13.9 \\
Total & & 100 \\
\hline
\end{tabular}

Note: Grading was performed according to USDA Honey Colour Grading Chart (USDA 1985)

Table 4.B. Effect of areas on color grading of honey $(\mathrm{N}=72)$

\begin{tabular}{llc}
\hline Region & Colour & Percent \\
\hline Dodoma & Water white & 1.4 \\
& Extra white & 5.6 \\
& White & 1.4 \\
& Extra light amber & 8.3 \\
Singida & Light amber & 8.3 \\
& White & 1.4 \\
& Extra light amber & 11.1 \\
& Light amber & 5.6 \\
Tabora & Amber & 6.9 \\
& Extra white & 5.6 \\
& White & 6.9 \\
& Light amber & 4.2 \\
Shinyanga & Amber & 8.3 \\
& Extra white & 2.8 \\
& White & 5.6 \\
& Extra light amber & 1.4 \\
& Light amber & 9.7 \\
Total & Amber & 5.6 \\
Note: Grading & was done according to USDA Honey Colour \\
Grading Chart & (USDA 1985). Values in parentheses present \\
several examinations (n) &
\end{tabular}

\section{Honey color}

The present research outcomes declare that honey samples from the western area possessed color descriptions ranging from light amber to amber to honey samples from the central area, which had color descriptions ranging from water white to amber (Table 4.A). On the other hand, honey samples from the Dodoma region had a relatively light color ranging from water white to light amber (Table 4.B).

Considering honeybee kind, the honey of stingless honey bee presented color grading of extra light amber (4.2\%), amber $(20.8 \%)$, and light amber $(25.0 \%)$. The honey of the Stinging honey bee was represented in most color grading ranging from water white $(1.4 \%)$ to light amber $(2.8 \%)$. The honey color allocation by honey kinds and area where the honey samples were gathered is expressed in Table 4.C.
Table 4.C. Colour grading of stinging and stingless honey bee's honey sampled from various areas in central and western areas in Tanzania $(\mathrm{N}=72)$

\begin{tabular}{|c|c|c|c|}
\hline Area & Colour & $\begin{array}{l}\text { Stingless } \\
(\%)\end{array}$ & $\begin{array}{c}\text { Honey kind } \\
\text { stinging } \\
(\%)\end{array}$ \\
\hline \multirow[t]{2}{*}{$\overline{\text { Bahi }}$} & Extra light amber & 0 & 4.2 \\
\hline & Light amber & 4.2 & 0 \\
\hline \multirow[t]{3}{*}{ Bukombe } & Extra light amber & 0 & 1.4 \\
\hline & Light amber & 0 & 2.8 \\
\hline & Amber & 4.2 & 0 \\
\hline \multirow[t]{3}{*}{ Dodoma town } & Extra white & 0 & 2.8 \\
\hline & Light amber & 4.2 & 0 \\
\hline & White & 0 & 1.4 \\
\hline \multirow[t]{3}{*}{ Inyonga } & Light amber & 1.4 & 0 \\
\hline & White & 0 & 4.2 \\
\hline & Amber & 2.8 & 0 \\
\hline \multirow[t]{4}{*}{ Issuna } & Extra light amber & 0 & 2.8 \\
\hline & Light amber & 1.4 & 0 \\
\hline & White & 0 & 1.4 \\
\hline & Amber & 2.8 & 0 \\
\hline \multirow[t]{3}{*}{ Kahama } & Extra white & 0 & 2.8 \\
\hline & Light amber & 4.2 & 0 \\
\hline & White & 0 & 1.4 \\
\hline \multirow[t]{3}{*}{ Kibaigwa } & Extra light amber & 4.2 & 0 \\
\hline & Extra white & 0 & 2.8 \\
\hline & Water white & 0 & 1.4 \\
\hline \multirow[t]{3}{*}{ Manyoni } & Extra light amber & 0 & 4.2 \\
\hline & Light amber & 1.4 & 0 \\
\hline & Amber & 2.8 & 0 \\
\hline \multirow[t]{2}{*}{ Nzega } & Extra white & 0 & 4.2 \\
\hline & Amber & 4.2 & 0 \\
\hline \multirow[t]{3}{*}{ Shinyanga town } & Light amber & 2.8 & 0 \\
\hline & White & 0 & 4.2 \\
\hline & Amber & 1.4 & 0 \\
\hline \multirow[t]{3}{*}{ Singida town } & Extra light amber & 0 & 4.2 \\
\hline & Light amber & 2.8 & 0 \\
\hline & Amber & 1.4 & 0 \\
\hline \multirow[t]{4}{*}{ Tabora town } & Extra white & 0 & 1.4 \\
\hline & Light amber & 2.8 & 0 \\
\hline & White & 0 & 2.8 \\
\hline & Amber & 1.4 & 0 \\
\hline
\end{tabular}

Note: Grading was done according to USDA Honey Colour Grading Chart (USDA,1985)

Results presented that honey of stingless honey bees had more of light amber to amber color. Honey color has been related to the nutritional value of the honey, where deeply pigmented honey (darkly colored) honey is superior in nutritional value to the one with light color. The darker the honey, the higher the mineral substance (Root 1980). Observations in this study suggest that stingless honey bees had relatively higher nutritional and medicinal value than stinging honey bees. It has also been informed that honey with dark color possesses a higher total phenolic substance and, consequently, higher anti-oxidant capacity (Montenegro et al. 2006). These examinations further comply with earlier findings (Table 2) that the stingless honey bee's honey had more medicinal attributes than the stinging honey bee's honey. 
Mineral profile of stinging and stingless honey bee

The results presented that the mineral substance of honey samples did not vary importantly $(\mathrm{P}>0.05)$ between central and western zones for $\mathrm{Zn}, \mathrm{Fe}$, and $\mathrm{Mg}$. However, $\mathrm{Ca}$ was importantly $(\mathrm{P}<0.001)$ higher in honey gathered from the central area, while $\mathrm{K}$ was higher in honey from the western area (Table 5.A). The dissimilarities in the mineral substance of honey could probably be because of dissimilarity in soil kinds that possess an influence on the floral mineral substance, which bees extract pollen and nectar (Seif and Alfadil 2009).

Results in Table 5.B declare the variability of the mineral substance of honey between areas. It was observed that there was no substantial $(\mathrm{P}>0.05)$ dissimilarity in the $\mathrm{Mg}$ substance of honey gathered from the four areas. However, the $\mathrm{Ca}$ substance was importantly $(\mathrm{P}<0.05)$ higher in honey samples gathered from Singida than that achieved from Shinyanga, Tabora, and Dodoma. A dissimilar trend was observed for $\mathrm{K}$, where honey gathered from Tabora, Shinyanga, and Singida areas was a more important $(\mathrm{P}<0.05)$ substance than in the Dodoma region.

Table 5.C presented that honey gathered from Issuna had a higher Zn substance, followed by Nzega, Manyoni, Bahi, Dodoma, and Singida. Iron was higher in honey from Inyonga, Shinyanga town, Singida town, and Issuna. Calcium was important $(\mathrm{P}<0.05)$, highest in honey gathered from Singida town, and lowest in honey gathered from Kahama $(\mathrm{P}<0.05)$. Nzega honey yielded the highest $\mathrm{Mg}$, whereas Kibaigwa honey had the lowest $\mathrm{Mg}$ substance. Potassium was importantly higher in Inyonga honey and lowest in Dodoma town honey $(\mathrm{P}<0.05)$.

The results in Table 5.D presented that potassium had the highest concentration, which was importantly $(\mathrm{P}<0.05)$ dissimilar from the rest in both kinds of honey. Honey sampled from Dodoma town had the lowest concentration. Kibaigwa honey had the least $\mathrm{Ca}$ substance $(\mathrm{P}<0.05)$. Zinc was the lowest in both kinds of honey, with a minimum value in Kibaigwa honey and a high value in Issuna honey. The dominance of $\mathrm{K}$ substance in honey is similar to the scrutinies made by Rodrigues-otero et al. (1994), who informed that $\mathrm{K}$ was the abundant and predominant element in honey. Also, thyme honey from Spain contained a relatively higher $\mathrm{K}$ concentration of $679 \mathrm{mg} / \mathrm{kg}$ (Terrab et al. 1994). Seif and Elifadili (2009) informed diversity in K substance because of floral kinds, whereby a range of 17.60 $\mathrm{mg} / \mathrm{kg}$ for Helianthus annus to $74.66 \mathrm{mg} / \mathrm{kg}$ for Acacia seyal was informed. The overall mean concentration of $\mathrm{K}$ observed in this study is within the range reported by other workers (Terrab et al. 1994). However, in the present study, the diversity of $\mathrm{K}$ concentration between areas and honey kinds (stinging honey bee from Dodoma town and stingless honey bee from Singida town) could be attributed to bee kinds and diversity in floral types.

Stingless honey presented a relatively higher $\mathrm{Zn}$ concentration, whereas honey from Issuna was highest and, importantly, $(\mathrm{P}<0.05)$ dissimilar from all other honey samples (Table 5.D). The other honey of stingless honey bees from Nzega, Manyoni, and Singida towns had higher $\mathrm{Zn}$ substances that did not differ importantly $(\mathrm{P}>0.05)$.
Stinging bees' honey had lower values importantly for $\mathrm{Zn}$ for all samples than stingless bees' honey. It was further examined that stinging bees' honey from Kibaigwa had the lowest $\mathrm{Zn}$ concentration. Generally, $\mathrm{Zn}$ was present in the lowest concentrations in relation to other minerals. These results are in accordance with Rodrigues-otero et al. (1994), who found $\mathrm{Zn}$ to be relatively lower while working with stinging honey bees coming from various floral kinds.

Table 5.A. The Effect of honey gathered from western and eastern zones on mineral substance

\begin{tabular}{lccccc}
\hline Area & \multicolumn{5}{c}{ Mineral substance } \\
& $\mathbf{Z n}$ & $\mathbf{F e}$ & $\mathbf{C a} / \mathbf{k g})$ & $\mathbf{M g}$ & $\mathbf{K}$ \\
\hline Central & $2.59^{\mathrm{a}}$ & $7.17^{\mathrm{a}}$ & $237.56^{\mathrm{a}}$ & $154.17^{\mathrm{a}}$ & $379.0^{\mathrm{b}}$ \\
Western & $2.02^{\mathrm{a}}$ & $8.55^{\mathrm{a}}$ & $162.0^{\mathrm{b}}$ & $143.91^{\mathrm{a}}$ & $531.56^{\mathrm{a}}$ \\
SE & \pm 0.23 & \pm 0.82 & \pm 19.55 & \pm 18.96 & \pm 154.15 \\
Significance & NS & NS & $* *$ & NS & $*$ \\
\hline
\end{tabular}

Note: Means bearing dissimilar superscripts along the same column are importantly dissimilar according to pdiff $\mathrm{P}<0.05$

Table 5.B. Effect of honey gathered from various areas of Tanzania on mineral substance.

\begin{tabular}{lccccc}
\hline Region & \multicolumn{5}{c}{$\begin{array}{c}\text { Mineral substance } \\
(\mathbf{m g} / \mathbf{k g})\end{array}$} \\
& Zn & Fe & $\mathbf{C a}$ & $\mathbf{M g}$ & K \\
\hline Dodoma & $2.24^{\mathrm{a}}$ & $3.68^{\mathrm{b}}$ & $169.55^{\mathrm{b}}$ & $134.41^{\mathrm{a}}$ & $281.79^{\mathrm{b}}$ \\
Shinyanga & $1.78^{\mathrm{b}}$ & $6.88^{\mathrm{ab}}$ & $131.36^{\mathrm{b}}$ & $130.43^{\mathrm{a}}$ & $504.82^{\mathrm{a}}$ \\
Singida & $2.93^{\mathrm{a}}$ & $10.67^{\mathrm{a}}$ & $305.57^{\mathrm{a}}$ & $173.94^{\mathrm{a}}$ & $476.22^{\mathrm{a}}$ \\
Tabora & $2.27^{\mathrm{a}}$ & $10.23^{\mathrm{a}}$ & $192.65^{\mathrm{b}}$ & $157.38^{\mathrm{a}}$ & $558.31^{\mathrm{a}}$ \\
Significance & $*$ & $*$ & $* * *$ & $\mathrm{NS}$ & $*$ \\
Overall mean & 2.31 & 7.86 & 199.78 & 149.04 & 455.29 \\
SE & \pm 0.33 & \pm 0.98 & \pm 24.97 & \pm 26.91 & \pm 76.34 \\
\hline
\end{tabular}

Note: Means bearing similar superscripts along the same column are not importantly dissimilar according to pdiff $(\mathrm{P}>0.05)$

Table 5.C. Effect of honey gathered from various areas on mineral substance.

\begin{tabular}{lccccc}
\hline Area & \multicolumn{5}{c}{ Mineral substance } \\
& $\mathbf{Z n}$ & $\mathbf{F e}$ & $\mathbf{C a}$ & $\mathbf{M g}$ & $\mathbf{K}$ \\
\hline Bahi & $2.63^{\mathrm{a}}$ & $7.12^{\mathrm{c}}$ & $215.09^{\mathrm{b}}$ & $155.34^{\mathrm{a}}$ & $447.89^{\mathrm{a}}$ \\
Bukombe & $1.12^{\mathrm{b}}$ & $4.65^{\mathrm{d}}$ & $119.82^{\mathrm{c}}$ & $127.79^{\mathrm{a}}$ & $436.35^{\mathrm{a}}$ \\
Dodoma town & $2.62^{\mathrm{a}}$ & $1.61^{\mathrm{e}}$ & $159.84^{\mathrm{c}}$ & $155.53^{\mathrm{a}}$ & $111.85^{\mathrm{c}}$ \\
Inyonga & $1.57^{\mathrm{b}}$ & $15.34^{\mathrm{a}}$ & $216.45^{\mathrm{b}}$ & $114.95^{\mathrm{a}}$ & $602.47^{\mathrm{a}}$ \\
Issuna & $3.29^{\mathrm{a}}$ & $10.80^{\mathrm{ab}}$ & $238.17^{\mathrm{b}}$ & $175.48^{\mathrm{a}}$ & $343.55^{\mathrm{a}}$ \\
Kahama & $1.67^{\mathrm{b}}$ & $4.22^{\mathrm{d}}$ & $91.72^{\mathrm{d}}$ & $141.23^{\mathrm{a}}$ & $496.56^{\mathrm{a}}$ \\
Kibaigwa & $1.47^{\mathrm{b}}$ & $2.32^{\mathrm{e}}$ & $133.73^{\mathrm{c}}$ & $92.38^{\mathrm{b}}$ & $285.61^{\mathrm{b}}$ \\
Manyoni & $2.89^{\mathrm{a}}$ & $10.38^{\mathrm{ab}}$ & $274.27^{\mathrm{b}}$ & $166.02^{\mathrm{a}}$ & $551.59^{\mathrm{a}}$ \\
Nzega & $2.95^{\mathrm{a}}$ & $8.44^{\mathrm{b}}$ & $190.71^{\mathrm{b}}$ & $189.29^{\mathrm{a}}$ & $531.22^{\mathrm{a}}$ \\
Shinyanga town & $2.55^{\mathrm{a}}$ & $11.76^{\mathrm{ab}}$ & $182.54^{\mathrm{b}}$ & $122.26^{\mathrm{a}}$ & $581.55^{\mathrm{a}}$ \\
Singida town & $2.62^{\mathrm{a}}$ & $10.81^{\mathrm{ab}}$ & $404.26^{\mathrm{a}}$ & $180.32^{\mathrm{a}}$ & $533.52^{\mathrm{a}}$ \\
Tabora town & $2.29^{\mathrm{a}}$ & $6.92^{\mathrm{c}}$ & $170.80^{\mathrm{b}}$ & $167.90^{\mathrm{a}}$ & $541.25^{\mathrm{a}}$ \\
Overall mean & 2.31 & 7.86 & 199.78 & 149.04 & 455.29 \\
SE & \pm 0.57 & \pm 1.31 & \pm 41.46 & \pm 48.62 & \pm 134.91 \\
\hline
\end{tabular}

Note: Means bearing similar superscripts along the same column are not importantly dissimilar according to pdiff $(\mathrm{P}>0.05)$ 
Table 5.D. Effect of zones, regions, areas, and honey kind on mineral substance

\begin{tabular}{|c|c|c|c|c|c|c|c|c|}
\hline \multirow[t]{2}{*}{ Area } & \multirow[t]{2}{*}{ Region } & \multirow[t]{2}{*}{ Area } & \multirow[t]{2}{*}{ Honey type } & \multicolumn{5}{|c|}{ Mineral substance (mg/kg) } \\
\hline & & & & $\mathbf{Z n}$ & $\mathbf{F e}$ & Ca & $\mathrm{Mg}$ & $\mathbf{K}$ \\
\hline \multirow[t]{12}{*}{ Central } & \multirow[t]{6}{*}{ Dodoma } & \multirow[t]{2}{*}{ Bahi } & Stingless & $4.12^{\mathrm{c}}$ & $7.84 \mathrm{dc}$ & $282.50^{\mathrm{cd}}$ & $259.57 \mathrm{bc}$ & $758.41^{\mathrm{d}}$ \\
\hline & & & Stinging & $1.13 \mathrm{~g}$ & $6.39 \mathrm{de}$ & $147.67^{d}$ & $51.10^{d}$ & $137.37^{f}$ \\
\hline & & \multirow[t]{2}{*}{ Town } & Stingless & $3.90^{\mathrm{c}}$ & $1.34 \mathrm{~g}$ & $228.42^{d}$ & $292.41^{b c}$ & $143.28^{c}$ \\
\hline & & & Stinging & $1.34 \mathrm{~g}$ & $1.88 \mathrm{~g}$ & $91.25^{\mathrm{f}}$ & $18.65^{f}$ & $80.42^{f}$ \\
\hline & & \multirow[t]{2}{*}{ Kibaigwa } & Stingless & $2.56^{\mathrm{e}}$ & $2.23 \mathrm{~g}$ & $237.50^{d}$ & $177.08^{\mathrm{c}}$ & $470.76^{\mathrm{e}}$ \\
\hline & & & Stinging & $0.38^{\mathrm{h}}$ & $2.40 \mathrm{~g}$ & $29.95 \mathrm{~g}$ & $7.67^{f}$ & $101.29 f$ \\
\hline & \multirow[t]{6}{*}{ Singida } & \multirow[t]{2}{*}{ Issuna } & Stingless & $5.29^{a}$ & $11.67^{b c}$ & $287.62^{c}$ & $273.92^{b c}$ & $423.37^{c}$ \\
\hline & & & Stinging & $1.28 \mathrm{~g}$ & $9.93^{c}$ & $188.73^{d}$ & $77.04^{\mathrm{d}}$ & $260.73^{f}$ \\
\hline & & \multirow[t]{2}{*}{ Manyoni } & Stingless & $4.55^{\mathrm{b}}$ & $12.36^{b}$ & $442.0^{b}$ & $277.46^{b c}$ & $931.39^{c}$ \\
\hline & & & Stinging & $1.22 \mathrm{~g}$ & $8.41^{\mathrm{c}}$ & $106.53 \mathrm{ef}$ & $54.57^{d}$ & $171.81^{\mathrm{f}}$ \\
\hline & & \multirow[t]{2}{*}{ Town } & Stingless & $4.43^{b c}$ & $12.10^{\mathrm{b}}$ & $508.70^{\mathrm{a}}$ & $281.98^{b c}$ & $951.10^{\mathrm{c}}$ \\
\hline & & & Stinging & $0.82^{h}$ & $9.52^{c}$ & $299.82^{c}$ & $78.65^{d}$ & $115.94^{f}$ \\
\hline \multirow[t]{14}{*}{ Western } & \multirow[t]{6}{*}{ Tabora } & \multirow[t]{2}{*}{ Inyonga } & Stingless & $1.56^{\mathrm{f}}$ & $12.53^{b}$ & $221.53^{\mathrm{cd}}$ & $164.82^{c}$ & $751.85^{\mathrm{d}}$ \\
\hline & & & Stinging & $1.57^{f}$ & $18.15^{\mathrm{a}}$ & $211.36^{\mathrm{cd}}$ & $65.07^{d}$ & $453.09 \mathrm{e}$ \\
\hline & & \multirow[t]{2}{*}{ Nzega } & Stingless & $4.56^{\mathrm{b}}$ & $10.80^{b c}$ & $319.46^{\mathrm{c}}$ & $350.52^{\mathrm{a}}$ & $894.72^{c}$ \\
\hline & & & Stinging & $1.34 \mathrm{~g}$ & $6.08 \mathrm{~d}^{\mathrm{e}}$ & $61.96^{f}$ & $28.07^{\mathrm{e}}$ & $167.72^{f}$ \\
\hline & & \multirow[t]{2}{*}{ Town } & Stingless & $3.22^{\mathrm{d}}$ & $8.32^{c}$ & $275.81^{\mathrm{cd}}$ & $310.76^{b}$ & $961.38^{b}$ \\
\hline & & & Stinging & $1.36^{\mathrm{g}}$ & $5.52^{\mathrm{e}}$ & $65.79^{f}$ & $25.04^{\mathrm{e}}$ & $121.12^{f}$ \\
\hline & \multirow[t]{8}{*}{ Shinyanga } & \multirow[t]{2}{*}{ Bukombe } & Stingless & $1.35^{\mathrm{g}}$ & $7.05^{\mathrm{d}}$ & $133.50^{\mathrm{e}}$ & $185.23^{\mathrm{c}}$ & $719.64^{\mathrm{a}}$ \\
\hline & & & Stinging & $0.88^{h}$ & $2.26 \mathrm{~g}$ & $106.14^{\mathrm{ef}}$ & $70.36^{\mathrm{d}}$ & $153.05^{\mathrm{f}}$ \\
\hline & & \multirow[t]{2}{*}{ Kahama } & Stingless & $1.42 \mathrm{~g}$ & $3.93^{\mathrm{fe}}$ & $94.76^{\mathrm{f}}$ & $244.01^{b c}$ & $792.59^{b}$ \\
\hline & & & Stinging & $1.92^{\mathrm{f}}$ & $4.50^{\mathrm{e}}$ & $88.68^{f}$ & $38.45^{\mathrm{e}}$ & $200.54^{f}$ \\
\hline & & \multirow[t]{4}{*}{ Town } & Stingless & $3.31^{\mathrm{d}}$ & $19.87^{\mathrm{a}}$ & $274.02^{\mathrm{cd}}$ & $205.87^{c}$ & $911.48^{\mathrm{a}}$ \\
\hline & & & Stinging & $1.80^{f}$ & $3.64^{\mathrm{fe}}$ & $91.06^{\mathrm{f}}$ & $38.66^{\mathrm{e}}$ & $251.63^{f}$ \\
\hline & & & SE & \pm 0.039 & \pm 0.182 & \pm 4.346 & \pm 3.138 & \pm 23.822 \\
\hline & & & Sign. level & $* * *$ & $* * *$ & $* * *$ & $* * *$ & $* * *$ \\
\hline
\end{tabular}

Note: Means bearing the same superscript within the same column are not statistically different (p $\geq 0.05)$ according to pdiff

The concentration of $\mathrm{Zn}$ observed in this study was relatively lower than that observed by Rodrigues-otero et al. (1994). They informed a minimum $\mathrm{Zn}$ concentration of $4.86 \mathrm{mg} / \mathrm{kg}$ to $9.61 \mathrm{mg} / \mathrm{kg}$. The dissimilarity could probably be because of the dissimilarity in vegetation and soil kinds. Soil and vegetation possess an influence on the mineral substance of honey. Root (1980) informed that minerals such as $\mathrm{K}, \mathrm{Cl}, \mathrm{S}, \mathrm{Na}, \mathrm{Zn}$, and $\mathrm{Ca}$ originate from the soil and get into honey via the plants. Furthermore, the plant mineral uptake varies with plant species.

Total iron (Fe) substance was slightly higher (Table 5.D) in stingless honey bees than that contained in stinging honey bees. Stingless honey bees from Shinyanga town had the highest $\mathrm{Fe}$ substance $(\mathrm{P}<0.05)$ that did not differ from the stinging honey bees from Inyonga. There were no substantial dissimilarities $(\mathrm{P}>0.05)$ in the Fe substance of stingless honey bees from Inyonga, Issuna, Manyoni, Singida town, and Nzega. The stingless honey bee from Dodoma town had the lowest Fe substance. According to this study, the observed iron concentration range of honey from Dodoma and Shinyanga towns had a lower minimum value of $2.05 \mathrm{mg} / \mathrm{kg}$ informed by Seif and Alfadil (2009). They worked on the honey originating from Azadirachta indica and Acacia seyal. The dissimilarity in iron substance could be attributed to dissimilarities in vegetation kinds where honey was extracted.
Generally, the total levels of $\mathrm{Ca}, \mathrm{Mg}$, and $\mathrm{K}$ were importantly $(\mathrm{P}<0.05)$ higher in stingless honey bees than that of stinging honeybees gathered from various areas (Table 5.D). The reasons contributing to the dissimilarity in the mineral profile between the two bee kinds could probably be because of the smaller size of stingless honey bees that enable them to penetrate deeper into the flower and extract more nutrients, also the behavior of stingless bees of not mixing pollen with honey, unlike a stinging bee that blends the two could contribute to the mineral superiority of stingless honey bee (Cortopassi et al. 2006). The concentration of calcium observed in the present study was dissimilar from the results informed by Seif and Elifadil (2009). They tested honey and found the concentration of $\mathrm{Ca}(\mathrm{mg} / \mathrm{kg})$ to range from 42.37 to 82.92 . The dissimilarity could probably be because of dissimilarity in soil that influences floral kinds and floral substances (Bereta et al. 2005).

The values of magnesium recorded in the current study (Table 5.D) are similar to the results informed by Seif and Elifadil (2009). They tested honey from dissimilar vegetation (Ziziphus spina, Acacia nilotica, Acacia seyal, Helianthus annus, and Azadirachta indica) and found magnesium concentration to range between23.67 to 177.15 $\mathrm{mg} / \mathrm{kg}$. Also, Parmas et al. (2000) specified a mineral mixture of honey from western Spain by flame photometric method and informed $\mathrm{mg}$ concentration of $23.9 \mathrm{mg} / \mathrm{kg}$. 
Antioxidant, total phenolic compounds, and Vitamin C content of stinging and stingless bee honey

Tables 6.A, 6.B, and 6.C present the effect of area, areas, and areas where samples were gathered on antioxidants, total phenols, and vitamin $\mathrm{C}$ substance of honey. Table 6.d shows the interaction effect of area, areas, and areas on the honey antioxidant, total phenols, and vitamin $\mathrm{C}$ substance.

Results in Table 6.A declare that there were no substantial $(\mathrm{P}>0.05)$ dissimilarities in antioxidant attributes (FRAP values) and total phenols of honey between the two areas. However, honey from the central area had importantly $(\mathrm{P}<0.05)$ higher vitamin $\mathrm{C}$ than the western area.

Looking at the effect of areas (Table 6.B), there were variations in FRAP values, total phenols, and vitamin $\mathrm{C}$ between areas. The diversity could be attributed to dissimilarity in soil kinds that influence the area's vegetation (Terrab et al. 2004). Antioxidant attributes (FRAP values) were importantly $(\mathrm{P}<0.05)$ higher in Shinyanga honey but did not differ from that of Singida and Tabora $(\mathrm{P}>0.05)$. The higher FRAP values of Shinyanga honey may be because of its stronger antioxidant attributes than all the other honey from other areas, indicating a greater reduction of $\mathrm{Fe}^{3+}$ to $\mathrm{Fe}^{2+}$ ions. Honey from Singida had an importantly $(\mathrm{P}<0.05)$ higher vitamin $C$ substance than that gathered from Tabora, Shinyanga, and Dodoma. These scrutinies suggest that honey from Singida could be a rich provenance of this vitamin than the ones gathered from Tabora, Shinyanga, and Dodoma.

Results in Table 6.C declare that there were no substantial $(\mathrm{P}>0.05)$ variations in total phenols in honey between areas where honey samples were gathered. Honey from Singida town yielded the highest vitamin $\mathrm{C}(\mathrm{P}<0.05)$ that did not differ from honey gathered from Dodoma, Shinyanga, Manyoni, Issuna, and Bukombe. The results of the present study presented that honey from Inyonga had an importantly $(\mathrm{P}<0.05)$ higher FRAP value that did not differ from that from Bukombe, Issuna, and Shinyanga towns, suggesting that honey from these areas could be utilized as a potential provenance of these compounds that are significant in removing the free radicals from the body that play a role in body immunity (Organic Facts, 2016). The honey gathered from Kibaigwa had the lowest FRAP value content.

The results of the present study presented that area where honey samples were gathered, honey kind, and interactions between the two factors importantly $(\mathrm{P}<0.01)$ influenced the FRAP value, total phenols, and vitamin $\mathrm{C}$ substance of the tested honey samples (Table 6.D).

The present research results have presented that FRAP values, total phenols, and Vitamin $\mathrm{C}$ substance were importantly $(\mathrm{P}<0.001)$ higher in the honey of stingless honey bees than that of the stinging honey bees in all sampled areas from all the areas in respective zones. The FRAP values range of 72.14-973.57 $\mu \mathrm{M} \mathrm{Fe}$ (II)/100 g examined in the present research are higher than the range of Bengal honey informed by Das et al. (2013) (101.6$622.1 \mu \mathrm{M} \quad \mathrm{Fe}(\mathrm{II}) / 100 \mathrm{~g})$ and that informed by Moniruzzaman et al. (2014) working with monofloral
Bangladeshi honey who examined a FRAP range of 116$786.3 \mu \mathrm{M}$ Fe (II)/100 g. The dissimilarity could be attributed to dissimilarity in vegetation kinds. However, the lower FRAP value (of Kibaigwa honey) suggests that the honey possesses relatively lower antioxidant attributes than all the other gathered honey samples, which might be connected to a less reduction of $\mathrm{Fe}^{3+}$ to $\mathrm{Fe}^{2+}$ ions (Moniruzzaman et al. 2013).

Table 6.A. Effect of honey gathered from western and central areas on antioxidant, total phenol, and vitamin c substance of honey.

\begin{tabular}{lccc}
\hline Area & $\begin{array}{c}\text { FRAP values } \\
(\boldsymbol{\mu M ~ F e}(\mathbf{I I}) / \mathbf{1 0 0 g})\end{array}$ & $\begin{array}{c}\text { Total phenol } \\
(\mathbf{m g} / \mathbf{1 0 0 g})\end{array}$ & $\begin{array}{c}\text { Vitamin C } \\
(\mathbf{m g} / \mathbf{1 0 0 g})\end{array}$ \\
\hline Central & $539.90^{\mathrm{a}}$ & $18.41^{\mathrm{a}}$ & $4.77^{\mathrm{a}}$ \\
Western & $611.58^{\mathrm{a}}$ & $15.24^{\mathrm{a}}$ & $3.51^{\mathrm{b}}$ \\
Mean & 575.74 & 16.82 & 4.14 \\
SE & \pm 44.14 & \pm 1.30 & \pm 0.36 \\
Significance & $\mathrm{NS}$ & $\mathrm{NS}$ & $*$ \\
\hline
\end{tabular}

Note: Means bearing the same superscript within the same column are not statistically different ( $\mathrm{p} \geq 0.05)$ according to pdiff. $\mathrm{NS}=$ Not substantial $(\mathrm{P}>0.05)$

Table 6.B. Effect of the region on antioxidant, total phenol, and vitamin $\mathrm{C}$ substance of honey

\begin{tabular}{|c|c|c|c|}
\hline Region & $\begin{array}{c}\text { FRAP values }(\mu \mathrm{M} \\
\mathrm{Fe}(\mathrm{II}) / \mathbf{1 0 0 \mathrm { g } )}\end{array}$ & $\begin{array}{c}\text { Total phenol } \\
(\mathrm{mg} / 100 \mathrm{~g})\end{array}$ & $\begin{array}{l}\text { Vitamin C } \\
(\mathrm{mg} / \mathbf{1 0 0 g})\end{array}$ \\
\hline Dodoma & $440.47^{\mathrm{b}}$ & $15.71^{\mathrm{b}}$ & $3.88^{\mathrm{b}}$ \\
\hline Shinyanga & $711.11^{\mathrm{a}}$ & $13.36^{\mathrm{b}}$ & $3.94^{\mathrm{b}}$ \\
\hline Singida & $639.33^{a}$ & $21.10^{\mathrm{a}}$ & $5.66^{\mathrm{a}}$ \\
\hline Tabora & $512.04^{\mathrm{ab}}$ & $17.12^{\mathrm{ab}}$ & $3.07^{\mathrm{b}}$ \\
\hline Significance & $*$ & $*$ & $*$ \\
\hline Overall mean & 575.74 & 16.82 & 4.14 \\
\hline SE & \pm 58.56 & \pm 1.78 & \pm 0.50 \\
\hline
\end{tabular}

Note: Means bearing the same superscript within the same column are not statistically different ( $\mathrm{p} \geq 0.05)$ according to pdiff. $*=$ Substantial at $\mathrm{P}<0.05$

Table 6.C. Effect of honey gathered from various areas on antioxidant, total phenol, and vitamin $\mathrm{C}$ substance of honey.

\begin{tabular}{lccc}
\hline Area & $\begin{array}{c}\text { FRAP values } \\
(\boldsymbol{\mu M ~ F e} \\
(\mathbf{I I}) / \mathbf{1 0 0 g})\end{array}$ & $\begin{array}{c}\text { Total } \\
\mathbf{p h e n o l} \\
(\mathbf{m g} / \mathbf{1 0 0 g})\end{array}$ & $\begin{array}{c}\text { Vitamin C } \\
(\mathbf{m g} / \mathbf{1 0 0 g})\end{array}$ \\
\hline Bahi & $625.42^{\mathrm{b}}$ & $17.91^{\mathrm{a}}$ & $3.83^{\mathrm{b}}$ \\
Bukombe & $815.57^{\mathrm{a}}$ & $12.88^{\mathrm{a}}$ & $4.25^{\mathrm{ab}}$ \\
Dodoma town & $431.92^{\mathrm{c}}$ & $17.21^{\mathrm{a}}$ & $6.29^{\mathrm{a}}$ \\
Inyonga & $836.37^{\mathrm{a}}$ & $22.39^{\mathrm{a}}$ & $3.92^{\mathrm{b}}$ \\
Issuna & $795.66^{\mathrm{a}}$ & $22.10^{\mathrm{a}}$ & $4.66^{\mathrm{a}}$ \\
Kahama & $613.15^{\mathrm{b}}$ & $14.11^{\mathrm{a}}$ & $2.07^{\mathrm{c}}$ \\
Kibaigwa & $264.06^{\mathrm{d}}$ & $12.0^{\mathrm{a}}$ & $1.51^{\mathrm{c}}$ \\
Manyoni & $541.49^{\mathrm{bc}}$ & $20.20^{\mathrm{a}}$ & $5.44^{\mathrm{a}}$ \\
Nzega & $415.95^{\mathrm{c}}$ & $15.36^{\mathrm{a}}$ & $3.06^{\mathrm{b}}$ \\
Shinyanga town & $704.61^{\mathrm{a}}$ & $13.08^{\mathrm{a}}$ & $5.52^{\mathrm{a}}$ \\
Singida town & $580.86^{\mathrm{bc}}$ & $21.0^{\mathrm{a}}$ & $6.86^{\mathrm{a}}$ \\
Tabora town & $283.81^{\mathrm{d}}$ & $13.61^{\mathrm{a}}$ & $2.24^{\mathrm{c}}$ \\
Overall mean & 575.74 & 16.82 & 4.14 \\
SE & \pm 56.59 & \pm 3.11 & \pm 0.80 \\
Significance & $*$ & $\mathrm{NS}$ & $*$ \\
\hline Nige & $* 3$ &
\end{tabular}

Note: Means bearing the same superscript within the same column are not statistically dissimilar according to pdiff $(\mathrm{P}>0.05)$; NS $=$ Not substantial $(\mathrm{P}>0.05) ; *=$ Substantial at $\mathrm{P}<0.05$ 
The observed total phenol (5.13-33.55 mg/100 g) in this research was lower than the range informed by Meda et al. (2005). They observed 27 honey samples from 18 multiflora, 2 honeydews, and 7 unifloral honey in Burkina Faso and informed total phenols of 32.59 to $114.5 \mathrm{mg} / 100$ g. However, the total phenols in the present research were greater than those informed by Lihu et al. (2005), working on several kinds of honey using HPLC and achieved total phenols ranging from 2.13 to $12.11 \mathrm{mg} / 100 \mathrm{~g}$. The diversity in phenol substance between these tested honey samples could be connected to dissimilarity in floral kinds, method of analysis, geographic origin as well as climatic characteristics of the sampled areas. Honey with high nonperoxidic substances, such as polyphenolic contents, is anticipated to have higher antimicrobial characteristics (Meda et al. 2005).

\section{Correlation between honey color, total phenols, and minerals}

Table 7 shows the correlation coefficient between honey colors, total phenols, and mineral substance in the honey samples. There was a positive and substantial $(\mathrm{P}<0.001)$ correlation between honey color and total phenolic compounds in the honey samples. These scrutinies suggest that the deeper the honey, the higher the phenolic compounds contained in the honey. Likewise, a substantial $(\mathrm{P}<0.01)$ and positive correlation existed between honey color and mineral substance, and total phenols contained in honey. Mineral substances, total phenols, and anti-oxidants have been positively related (Montenegro et al. 2006). Therefore, honey with deep color is assumed to possess high anti-microbial activities; thus, the deeper the color the honey possesses, the broader the spectrum of antimicrobial, fungal, and yeast (Kumar et al. 2010).

Table 6.D. The effect of zones, regions, areas, and honey kinds on antioxidants, total phenols, and vitamin C substances.

\begin{tabular}{|c|c|c|c|c|c|c|}
\hline Area & Region & Area & Honey type & $\begin{array}{c}\text { FRAP values } \\
(\mu \mathrm{MFe}(\mathrm{II}) / \mathbf{1 0 0 \mathrm { g } )}\end{array}$ & $\begin{array}{l}\text { T phenol } \\
\text { (mg/100g) }\end{array}$ & $\begin{array}{l}\text { Vitamin C } \\
(\mathrm{mg} / \mathbf{1 0 0 g})\end{array}$ \\
\hline \multirow[t]{12}{*}{ Central } & \multirow[t]{6}{*}{ Dodoma } & \multirow[t]{2}{*}{ Bahi } & Stingless & $816.07^{\mathrm{a}}$ & $24.69^{\mathrm{bc}}$ & $5.45^{\mathrm{d}}$ \\
\hline & & & Stinging & $434.76^{c}$ & $11.14^{\mathrm{h}}$ & $2.22^{\mathrm{ef}}$ \\
\hline & & \multirow[t]{2}{*}{ Town } & Stingless & $640.71^{\mathrm{b}}$ & $26.39^{b}$ & $10.99^{\mathrm{a}}$ \\
\hline & & & Stinging & $223.12^{\mathrm{d}}$ & $8.03^{\mathrm{i}}$ & $1.60^{\mathrm{f}}$ \\
\hline & & \multirow[t]{2}{*}{ Kibaigwa } & Stingless & $455.99^{c}$ & $17.07^{\mathrm{ef}}$ & $2.54^{\mathrm{ef}}$ \\
\hline & & & Stinging & $72.14^{\mathrm{e}}$ & $6.93^{\mathrm{i}}$ & $0.47^{\mathrm{g}}$ \\
\hline & \multirow[t]{6}{*}{ Singida } & \multirow[t]{2}{*}{ Issuna } & Stingless & $970.48^{a}$ & $25.23^{b}$ & $7.69^{c}$ \\
\hline & & & Stinging & $620.83^{b}$ & $18.98^{\mathrm{de}}$ & $1.63^{\mathrm{f}}$ \\
\hline & & \multirow[t]{2}{*}{ Manyoni } & Stingless & $612.03^{b}$ & $27.23^{b}$ & $8.67^{\mathrm{bc}}$ \\
\hline & & & Stinging & $470.95^{\mathrm{c}}$ & $13.18^{\mathrm{gh}}$ & $2.21^{\mathrm{ef}}$ \\
\hline & & \multirow[t]{2}{*}{ Town } & Stingless & $645.90^{\mathrm{b}}$ & $25.67^{b}$ & $9.80^{\mathrm{b}}$ \\
\hline & & & Stinging & $515.82^{c}$ & $16.35^{\text {ef }}$ & $3.92^{\mathrm{e}}$ \\
\hline \multirow[t]{14}{*}{ Western } & \multirow[t]{6}{*}{ Tabora } & \multirow[t]{2}{*}{ Inyonga } & Stingless & $822.50^{\mathrm{a}}$ & $33.55^{\mathrm{a}}$ & $5.48^{d}$ \\
\hline & & & Stinging & $850.24^{\mathrm{a}}$ & $11.24^{\mathrm{h}}$ & $2.35^{\mathrm{ef}}$ \\
\hline & & \multirow[t]{2}{*}{ Nzega } & Stingless & $557.26 b^{c}$ & $24.07^{\mathrm{bc}}$ & $3.95^{\mathrm{e}}$ \\
\hline & & & Stinging & $274.64^{\mathrm{d}}$ & $6.64^{\mathrm{i}}$ & $2.17^{\mathrm{ef}}$ \\
\hline & & \multirow[t]{2}{*}{ Town } & Stingless & $322.16^{\mathrm{d}}$ & $22.09^{c}$ & $2.74^{\mathrm{ef}}$ \\
\hline & & & Stinging & $245.45^{\mathrm{d}}$ & $5.13^{\mathrm{i}}$ & $1.73^{\mathrm{f}}$ \\
\hline & \multirow[t]{8}{*}{ Shinyanga } & \multirow[t]{2}{*}{ Bukombe } & Stingless & $848.90^{\mathrm{a}}$ & $15.13^{\mathrm{f}}$ & $5.51^{\mathrm{d}}$ \\
\hline & & & Stinging & $782.23^{\mathrm{a}}$ & $10.65^{\mathrm{h}}$ & $2.97^{\mathrm{e}}$ \\
\hline & & \multirow[t]{2}{*}{ Kahama } & Stingless & $871.07^{\mathrm{a}}$ & $13.87^{\mathrm{gh}}$ & $2.53^{\mathrm{ef}}$ \\
\hline & & & Stinging & $355.24^{\mathrm{d}}$ & $14.36^{\mathrm{fg}}$ & $1.61^{\mathrm{f}}$ \\
\hline & & \multirow[t]{4}{*}{ Town } & Stingless & $973.57^{\mathrm{a}}$ & $19.96^{\mathrm{d}}$ & $9.25^{\mathrm{b}}$ \\
\hline & & & Stinging & $435.64^{c}$ & $6.19^{\mathrm{i}}$ & $1.78^{\mathrm{f}}$ \\
\hline & & & SE & \pm 61.79 & \pm 0.26 & \pm 4.70 \\
\hline & & & Significance & $*$ & $* * *$ & $* * *$ \\
\hline
\end{tabular}

Note: Means bearing the same superscript within the same column are not statistically different $(\mathrm{p} \geq 0.05)$ according to pdiff. NS $=$ Not substantial $(\mathrm{P}>0.05)$. $* * *=$ Substantial at $\mathrm{P}<0.001$

Table 7. The correlation coefficient between honey color, total phenols, and mineral content

\begin{tabular}{|c|c|c|c|c|c|c|c|}
\hline & Colour & Total phenols & Zn & $\mathbf{F e}$ & Ca & Mg & $\mathbf{K}$ \\
\hline$\overline{\text { Colour }}$ & 1 & & & & & & \\
\hline Total phenols & $0.7729 * * *$ & 1 & & & & & \\
\hline $\mathrm{Zn}$ & $0.6739 * * *$ & $0.6928 * * *$ & 1 & & & & \\
\hline $\mathrm{Fe}$ & $0.4225 * * *$ & $0.4295 * * *$ & $0.3462 * *$ & 1 & & & \\
\hline $\mathrm{Ca}$ & $0.6505^{* * *}$ & $0.7549 * * *$ & $0.7554 * * *$ & $0.5456^{* * *}$ & 1 & & \\
\hline $\mathrm{Mg}$ & $0.8587 * * *$ & $0.7821 * * *$ & $0.8279 * * *$ & $0.2916^{*}$ & $0.7238 * * *$ & 1 & \\
\hline K & $0.7598 * * *$ & $0.4045 * * *$ & $0.4133 * * *$ & $0.3644 * *$ & $0.3644 * * *$ & $0.6969 * * *$ & 1 \\
\hline
\end{tabular}

Note: $* * *=\mathrm{P}<0.001 \quad * *=\mathrm{P}<0.01 \quad *=\mathrm{P}<0.05$ 
In conclusion, honey samples gathered from the western area had more capability to inhibit microbial growth than those gathered from the central area. In addition, honey from Shinyanga in the western area had the highest capability to inhibit microbial growth, followed by Singida, Dodoma, and Tabora. On the other hand, honey samples from Nzega and Inyonga had the highest capability to inhibit microbial growth, followed by honey samples from Shinyanga town, Bukombe, and Kahama. C. albicans was more sensitive to impediment by the honey of stingless honey bees, followed by Staphylococcus saprophyticus and $S$. typhi, whereas E. coli was not influenced by the honey of stinging honey bees. Honey of Stinging honey bee was more effective in inhibiting the growth of A. flavus and $C$. albicans. It was generally examined that honey of stingless honey bees had higher values for total phenols, antioxidants, and vitamin $\mathrm{C}$ contents than that of the stinging honey bee. Honey from Inyonga, Manyoni, Dodoma town, Issuna, Singida town, Shinyanga town, and Nzega showed relatively higher total phenol, antioxidant, and vitamin $\mathrm{C}$ substance. There was no substantial $(\mathrm{P}>0.05)$ dissimilarity in $\mathrm{pH}$ between stinging and stingless honey samples. However, total decreasing sugars and mineral substances were higher in honey samples of a stingless honey bee than that of a stinging honey bee. Total decreasing sugar was higher in honey from Kahama, Shinyanga town, Bukombe, Tabora town, Nzega, Issuna, Dodoma town, and Bahi. High-decreasing sugars were also examined in the honey of stinging honey bees from Shinyanga town. A similar trend was examined for mineral substance, where honey of stingless honey bees bore more minerals. Thus, it possessed darker color (light amber to amber) than the honey of a stinging honey bee. There was a positive and substantial $(\mathrm{P}<0.05)$ correlation between total phenols, honey color, and mineral substance of honey, suggesting that the deeper the color of the honey, the higher the mineral and total phenol substance. Therefore, honey with deep color is assumed to possess high antimicrobial activities; thus, the deeper the color the honey possesses, the broader spectrum of anti-microbial growth. Generally, honey of stingless honey bees is superior to honey of stinging honey bees in antimicrobial and antioxidant attributes, total decreasing sugars, total phenol, vitamin $\mathrm{C}$, and mineral substance.

\section{REFERENCES}

Alisi CS, Ojiako OA, Igwe CU, Ujowundu CO, Anugweje K, Okwu GN. 2012. Antioxidant content and free radical scavenging activity of honeys of Apis mellifera of Obudu Cattle Ranch. Int J Biochem Res Rev 2 (4): 164-75.

Alvarez-Suarez JM, Tulipani S, Romandini S, Bertoli E, Battino M. 2010. Contribution of honey in nutrition and human health: a review. Mediterr J Nutr Metab 3: 15-23.

AOAC. 2000. Official methods of analysis. Association of Official Analytical Chemists. WashingtonDC. USA.

AOAC. 2007. Official methods of Analysis. Association of Official Analytical Chemists. WashingtonDC. USA.

Aparna AR, Rajalakshmj D. 1999. Honey-Its characteristics, sensory aspects, and applications. Food Rev Intl 15: 455-471.
Benzie IFF, Strain JJ. 1996. The ferric reducing ability of plasma (FRAP) as a measure of antioxidant power: The FRAP assay. Anal Biochem 239 (1): 70-76.

Beretta G, Granata P, Ferrero M, Orioli M, Facino RM. 2005. Standardization of antioxidant properties of honey by a combination of spectrophotometric/fluorimetric assays and chemometrics. Anal Chim Acta 533: 185-191.

Bogdanov S, Martin P, Lullmann C. 1997. Harmonised methods of the European Honey Commission. Apidologie 28: 1-59.

Cabrera L, Cespedes E, Nava R, Ojeda de Rodriguez G. 2006. Antibacteria activity with honey. J Antimicrob Agents 16: 556-5563.

Candiracci M, Piatti E, Dominguez BM, Garcial AD, Morgado BD, Gutierrez JF, Parrado JC. 2012. Anti-inflammatory activity of a honey flavonoid extract on lipopolysaccharide-Activated N13 Microbial Cells. J Agric Food Chem 60: 4-11.

Codex Alimentarius Commission. 2001. Codex Standard 12. Revised codex standard for honey, standard and standard methods.

Cooper R. 2007. Honey in wound care: Antibacterial properties.GMS Int J Antimicrob Agents 2: 1-3.

Cortopassi LMC, Imperatriz FVL, Roubik DW, Dollin AH, Aguilar I, Venturieri G C. 2006. Global meliponiculture; challenges and opportunities. Apidologie 37 (2): 275-292.

Das A, Mukherjee A, Dhar P. 2013. Characterization of antioxidants and antioxidative properties of various unifloral honeys procured from West Bengal, India. IOSR J Environ Sci Toxicol Food Technol 7 (3): $56-63$

Eva C. 1999. The World History of Bee Keeping and Honey Hunting. Redwood Boos Ltd, Trowbridge Great Britain.

FAOSTAT. 2014. Honey. [http: //faostat.fao.org/browse] site visited on $17 / 5 / 2015$

French VM, Cooper RA, Molan PC. 2005. The antibacterial activity of honey against coagulase-negative Staphylococci. J Antimicrob Chemother 56: 228-31.

Garcia A, Soto D, Romo C. 1986. Honey composition and properties. Food Chem 14: 185-191.

Gidamis AB, Chove BE, Shayo BS, Nnko SA, Bangu NT. 2004. Quality evaluation of honey harvested from selected areas in Tanzania with special emphasis on Hydroxymethyl Furfural (HMF) levels. Plant Foods Hum Nutr 59: 129-132.

Khan FR, Abadin ZU, Rauf N. 2007. Honey nutritional and medicinal value. Int J Clin Pract 61: 1705-1707.

Kumar SKP, Debjit B, Chandira MR. 2010. Medicinal uses and health benefits of honey: J Chem Pharm Res 2 (1): 385-395.

Lihu F, Dehghn NG, Mirtajaldini M. 2005. Honey types and determination of potentials for floral authentication using extraction and high-pressure liquid chromatography (HPLC) method. J Basic Appl Sci 4: 24-42.

Manning R. 2000. Fatty Acids in Pollen, a Review of their Importance for Honey Bees. Agriculture WA, Bentley Delivery Center, Western Australia.

Meda A, Lamien CE, Romito M, Milogo J, Nacoulma. 2005. Determination of the total phenolic, flavonoid, and proline contents in Burkina Fasan honey, as well as their radical scavenging activity. Food Chem 91: 571-577.

Mohammad SK, Mohamad FM, Daneshwar P. 2012. Anti-microbial and physicochemical properties of processed and raw honeys of Mauritius, J Adv Infect Dis 2: 25-36.

Mohapatra G, Paseiro P, Simila J. 2010. Antimicrobial analysis of raw and processed honey from India. Food Chem 49: 169-171.

Molan PC. 1992. The antibacterial activity of honey. Int J Clin Pract 73: $5-28$.

Molan PC. 1999a. Why honey is effective as a medicine. 1. Its use in modern medicine. J Apic Res 80: 80-92.

Moniruzzaman M, Chua Y, Pasupuleti VR, Mohammad NH, Siti AB, Siti AS, Siew HG. 2014. Identification of phenolic acids and flavonoids in monofloral honey from Bangladesh by high-performance liquid chromatography: Determination of antioxidant capacity. BioMed Research International article.

Moniruzzaman M, Ibrahim K, Siti AS, Siew HG, 2013. Physicochemical and antioxidant properties of Malaysian honeys produced by Apis cerana, Apis dorsata, and Apis mellifera. Research article, Human Genome Centre, School of Medical Sciences, University Sains Malaysia. 
Montenegro G. 2006. Natural composition based on Chilean unifloral honey extract from native plant species for bacterial infection control in vegetables at all. J Med Food 35 (2): 181-190.

Muruke MH. 2014. Assessment of quality of Tanzanian honey based on physicochemical properties. Food Sci Quality Manag 33: 61-72.

Mwakatobe A, Mlingwa C. 2004. The status of Tanzanian honey TradeDomestic and International Market.

Organic Facts: Health Benefits of Honey. 2016. [https: //www.organicfacts.net/health-benefits/health-benefits-of-honey.html] site visited on 23.9.2016

Panaromic Hill Honey Collective. 2013. In Muruke. 2013. Assessment of quality of Tanzanian honey based on phytochemical properties. Food Sci Qual Manag 33: 61-72.

Parmas AMG, Barez JG, Villanova RG, Pala TR, Albajar RA, Sanchez JS. 2000.Geographical discrimination of honeys by using minera composition and common chemical parameters. J SciFood Agric 80: 157-165.

Rahman MM, Allan R, Azinun MS. 2010. Antibacterial activity of propolis and honey against Staphylococcus aureus and Escherichia coli. African J Microbiol Res 4 (16) 1872-1878.

Rodriguez OG. 2004. Characterization of honey produced in Venezuela. Food Chem 84 (4): 499-502.

Rodriguez-Otero JL, Paseiro P, Simal J, Cepeda A. 1994. Mineral content of the honeys produced in Galicia (North-west Spain). Food Chem 49: $169-171$.
Root ERG. 1980. The ABC and XYZ of Bee Culture. The A. I. Root Company, Medina, Ohio, U.S.A.

Roubik DW. 2006. Stingless bee nesting biology. Apidologies 37 (2): 124-143.

Seif EAM, Elfadil EB. 2009. Protein structure, physicochemical properties, and mineral composition of Apis mellifera honey samples of different floral origin. J Basic Appl Sci 3 (3): 2477-2483.

Singleton VL, Orthofer R, Lamuela-Raventós RM. 1999. Analysis of total phenols and other oxidation substrates and antioxidants by means of folin-ciocalteu reagent. J Food Chem299: 152-178.

Stefan B. 2009. Bee Product Science. CRC Press. New York, USA.

Terrab A, Recamales AF, Hernanz D, Heredia FJ. 2004. Characterization of Spanish thyme honey by their physical-chemical and mineral contents. J Food Chem 88: 537-542.

URT. 2003. National Beekeeping Policy. Ministry of Natural Resources and Tourism, Dar-es-Salam, Tanzania.

USDA. 1985. United States Standards for Grades of Extracted Honey. U.S. Department of Agriculture, Washington, D.C.

Wahdan HAL. 1998. Causes of the antimicrobial activity of honey. J Food Res 26: 26-31.

White JW. 1978. Honey. Advances in Food Research. Academic Press, New York. 